\title{
Surface modification of carbon fuels for direct carbon fuel cells
}

Xiang Li, ${ }^{1}$ Zhonghua Zhu, ${ }^{1}$ Jiuling Chen, ${ }^{1}$ Roland De Marco ${ }^{2}$, Andrew Dicks, ${ }^{1}$ John Bradley, ${ }^{1}$ Gaoqing Lu ${ }^{1}$

${ }^{1}$ Division of Chemical Engineering, School of Engineering, University of Queensland, Brisbane 4072

Australia

${ }^{2}$ Department of Applied Chemistry, Curtin University Technology, Perth, Australia

\begin{abstract}
The direct carbon fuel cell (DCFC) is a promising power generation device, which has much higher efficiency (80\%) and less emission than conventional coal-fired power plants. Two commercial carbons (one activated carbon and one carbon black) with pre-treatment of $\mathrm{HNO}_{3}, \mathrm{HCl}$ and air plasma are tested in the DCFC. The correlation between the surface properties and electrochemical performances of carbon fuels is explored. The $\mathrm{HNO}_{3}$ - treated carbon fuels have the highest electrochemical reactivity in the DCFC due to the largest degree of surface oxygen functional groups The overall effect on changing the electrochemical reactivity of carbon fuels is of the order $\mathrm{HNO}_{3}>$ air plasma $\approx \mathrm{HCl}$. Product gas analysis indicates that complete oxidation of carbon to $\mathrm{CO}_{2}$ can be achieved at $600-700{ }^{\circ} \mathrm{C}$.
\end{abstract}

Keywords: Carbon; Direct carbon fuel cell; Surface treatment; Electrochemical reactivity

*Corresponding author: z.zhu@uq.edu.au; fax 61733654199 


\section{Introduction}

The direct carbon fuel cell (DCFC), the only fuel cell capable of converting solid carbon into electricity without a reformation process, is gaining increased attention due to its high conversion efficiency with low pollution. The solid carbon fuels in the DCFC can be produced easily from various resources, including coal, petroleum, natural gas and even biomass. Compared with other hydrogen based fuel cells, the DCFC has the significant thermodynamic advantage of a near zero entropy change at high temperature, which means the theoretical electrochemical efficiency of the DCFC $(\Delta \mathrm{G} / \Delta \mathrm{H})$ is almost $100 \%$ [1-7]. Even under practical conditions, about $80 \%$ efficiency can be reached in the DCFC system. Secondly, the activities (chemical potentials) of both reactant carbon and the product carbon dioxide are fixed, resulting in a stable carbon anode potential during practical operation $[2,3]$. Thirdly, the DCFC has lower emissions compared with conventional power plants. In principle, the off-gas can be pure carbon dioxide, which can be directly collected for industrial use [1] or sequestration.

Various electrolytes such as molten carbonates [2, 3, 8-13], molten hydroxides [7, 14-17] and Yttria Stabilised Zirconia (YSZ)-based solid electrolytes [18, 19] have been used in DCFCs. The latest development in DCFC technology is to utilize highly reactive carbon particulates dispersed in a molten carbonate electrolyte, which flows between the anode and cathode at high temperature [2, 3, 9, 11, 12]. The anode and cathode reactions may be expressed as Eq. (1) and Eq. (2). The overall reaction and anode potential are given by Eq. (3) and Eq. (4) [2, 12].

Anode reaction: $\mathrm{C}+2 \mathrm{CO}_{3}{ }^{2-} \rightarrow 3 \mathrm{CO}_{2}+4 \mathrm{e}^{-}$

Cathode reaction: $\mathrm{O}_{2}+2 \mathrm{CO}_{2}+4 \mathrm{e}^{-} \rightarrow 2 \mathrm{CO}_{3}{ }^{2-}$

Overall reaction: $\quad \mathrm{C}+\mathrm{O}_{2} \rightarrow \mathrm{CO}_{2}$

Where the anode potential is given by:

$\mathrm{E}_{\text {anode }}=\mathrm{E}^{\mathbf{o}}-(\mathrm{RT} / 4 \mathrm{~F}) \ln \left[\mathrm{P}^{3} \mathrm{CO} 2(\mathrm{w})\right]+(\mathrm{RT} / 4 \mathrm{~F}) \ln \left[\mathrm{P}^{2}{ }_{\mathrm{CO} 2}(\mathrm{r}) \mathrm{P}_{\mathrm{O} 2}(\mathrm{r})\right]$

and $\mathrm{E}^{\mathrm{o}}$ is the anode potential at standard conditions, $\mathrm{R}$ is the universal gas constant, $\mathrm{T}$ is the cell temperature, $\mathrm{P}_{\mathrm{CO} 2}(\mathrm{w})$ is the $\mathrm{CO}_{2}$ partial pressure at the working electrode, while $\mathrm{P}_{\mathrm{CO} 2}(\mathrm{r})$ and $\mathrm{P}_{\mathrm{O} 2}(\mathrm{r})$ are the partial pressures of $\mathrm{CO}_{2}$ and $\mathrm{O}_{2}$ at the reference electrode, respectively. 
Various carbon fuels have been tested in different DCFC apparatus to investigate the efficacy of carbon fuels in the anodic reaction. It has been found that disordered carbon is more reactive due to the existence of more edge sites and defects, but that graphitic carbon with high electrical conductivity also benefited the electrochemical reaction. The physical and chemical properties of carbon fuels can thus influence their electrochemical performance. Weaver et al. [13] observed that carbon fuels with high surface area such as devolatilized coal are more accessible to the anode reaction, while Cooper's group concluded that the effect of carbon surface area on discharge rate is not strong $[2,3]$. Consequently, ways of improving the electrochemical reactivity of carbon fuels in the anode [i.e., reaction of Eq. (1)] is still a major obstacle to the application of the DCFC.

Carbon materials are widely used in fuel cells as electrodes, as electro-catalyst supports and as hydrogen storage materials [20]. It is well known that the kinetics of the electrochemical processes involving carbon strongly depend on the surface characteristics of the carbons used. Surface treatments including acid treatment, heat treatment, laser treatment, plasma treatment and electrochemical treatment, are usually applied to the carbon materials in order to enhance their electrochemical reactivity [21]. To our knowledge, no published study has been conducted on the relationship between the surface modification of carbon fuels and their electrochemical performances in the DCFC (rather than carbon electrodes). In this study, a comparative investigation of the DCFC performance of two commercial carbon fuels including one activated carbon (AC) and one carbon black (CB) with different surface treatments employing $\mathrm{HNO}_{3}, \mathrm{HCl}$ and plasma treatments was deemed appropriate. The electrochemical reactivities of these carbon fuels in the DCFC were systematically analysed, and correlated with physical and chemical characterization data on the surface chemistry and physics of the fuels.

\section{Experimental}

\subsection{Preparation of carbon fuels}

A commercial granular activated carbon (Calgon BPL, 0.25-0.45 mm particle size) and a carbon black sample (Koppers Continex N220, 0.1-0.2 mm particle size) were selected as the starting 
samples, which were designated as $\mathrm{AC}$ and $\mathrm{CB}$, respectively. The acid treatment of $\mathrm{AC}$ and $\mathrm{CB}$ was by immersion in $4 \mathrm{M} \mathrm{HNO}_{3}$ and $4 \mathrm{M} \mathrm{HCl}$ at room temperature for 24 hours with subsequent washing with distilled water. These acid-treated carbon fuels are designated as $\mathrm{AC}-\mathrm{HNO}_{3}, \mathrm{AC}-\mathrm{HCl}$, $\mathrm{CB}-\mathrm{HNO}_{3}$ and $\mathrm{CB}-\mathrm{HCl}$, respectively. Air plasma treatment for the $\mathrm{CB}$ samples was carried out using a microwave generator (Sairem, France) with $2.45 \mathrm{GHz}$ frequency and $100 \mathrm{~W}$ power. The reactor was first evacuated to a pressure of about $8000 \mathrm{~Pa}$ (60 Torr), then the $\mathrm{CB}$ was treated in air plasma for $15 \mathrm{~min}$, which is designated as CB-Plasma.

\subsection{Characterization of carbon fuels}

XRD characterization of the carbon samples was performed on a Rigaku Miniflex X-ray diffractometer $(40 \mathrm{kV}, 30 \mathrm{~mA})$ with $\mathrm{Cu} \mathrm{K \alpha}$ radiation at a scanning rate of $2 \%$ min in the $2 \theta$ range from $10^{\circ}$ to $90^{\circ}$. The average size of carbon crystallite was calculated from the Debye-Scherrer equation:

$L=\frac{K \lambda}{\beta \cos \theta}$

where $\lambda$ is the wavelength of the $\mathrm{X}$-rays, $\theta$ is the diffraction angle, $\mathrm{K}$ is the shape factor, and $\beta$ is the peak width at half-maximum intensity. The value of $\mathrm{K}=0.89$ and 1.84 [35] were used for Lc and La respectively. The crystallite size perpendicular to the basal plane, Lc, is obtained from the (002) reflection, while the crystallite size parallel to the basal plane, La, is calculated using the (100) reflection corresponding to the a-axis unit cell parameter.

Electrical conductivities were measured by a Frequency Response Analyser (Solartron SI1260). Approximately $200 \mathrm{mg}$ of carbon material was pressed into a small pellet (13mm diameter) at the lowest pressure needed to form a compact, $150 \mathrm{~kg} \mathrm{~cm}^{-2}$. The sample pellet was then placed between two gold-plated blocking electrodes of area $0.5 \mathrm{~cm}^{2}$ in a jig of known resistance and the sample impedance measured over the frequency range $1 \mathrm{MHz}$ to $1 \mathrm{~Hz}$ using a sinusoidal excitation amplitude of $10 \mathrm{mV}$ root mean square (rms). Finally, the bulk conductivity $\sigma_{\text {( }}\left(\mathrm{S} \mathrm{cm}^{-1}\right)$, could be calculated from Equation:

$\sigma=l /\left[\left(r-r_{0}\right) A\right]$ 
where $l$ is the sample pellet thickness $(\mathrm{cm}), r$ is the tested sample resistance $(\Omega)$, taken as the impedance at zero phase angle, $\Omega), r_{0}$ is the rig short circuit resistance $(\Omega)$ and $A$ is the electrode contact area $\left(0.5 \mathrm{~cm}^{2}\right)$.

$\mathrm{N}_{2}$ adsorption/desorption experiments were carried out in Quadrasorb adsorption analyzer (Quantachrome, USA) at $-196{ }^{\circ} \mathrm{C}$. The specific surface areas $\left(\mathrm{S}_{\mathrm{BET}}\right)$ of the carbon samples were calculated by the multiple point Brunauer-Emmett-Teller (BET) method in the relative pressure range $\mathrm{P} / \mathrm{P}_{\mathrm{o}}=0.05-0.25$. The total pore volume $\left(\mathrm{V}_{\text {total }}\right)$ is derived from the adsorption amount at a relative pressure of $\mathrm{P} / \mathrm{P}_{\mathrm{o}}=0.99$. The average pore diameters $\left(\mathrm{D}_{\text {pore }}\right)$ of carbons were calculated by the available software (QuadraWin V2.0) which applies Barrett-Joyner-Hallenda (BJH) method. The micropore volume $\left(\mathrm{V}_{\text {micro }}\right)$ and surface area $\left(\mathrm{S}_{\text {micro }}\right)$ of samples were also calculated by the available software (QuadraWin V2.0) which applies Dubinin-Radushkevich (DR) method. Prior to the $\mathrm{N}_{2}$ adsorption mesearments, all samples were degassed at $200{ }^{\circ} \mathrm{C}$ for overnight.

Temperature programmed oxidation (TPO) measurements were conducted under air-flow (80 $\mathrm{ml} / \mathrm{min}$ ) in a Thermogravimetric Analyser (Shimadzu TGA-50). Samples were loaded into a platinum pan and heated under nitrogen atmosphere from room temperature to $200{ }^{\circ} \mathrm{C}$, and held for 1 hour to remove the adsorption water, and then the temperature was further increased to $900{ }^{\circ} \mathrm{C}$ in air $(80 \mathrm{ml} / \mathrm{min})$ with a heating rate of $10^{\circ} \mathrm{C} \mathrm{min}^{-1}$.

The X-ray photoelectron spectroscopy (XPS) measurements were conducted using a Kratos Axis Ultra XPS system incorporating a $165 \mathrm{~mm}$ hemispherical electron energy analyser. The incident radiation was monochromatic $\mathrm{Al} \mathrm{K \alpha} \mathrm{X}$-ray $(1486.6 \mathrm{eV})$ at $150 \mathrm{~W}$ (15 kV, $10 \mathrm{ma})$. Survey scans were taken at an analyser pass energy of $160 \mathrm{eV}$, and performed over a $1200 \mathrm{eV}$ binding energy range using a $1.0 \mathrm{eV}$ step and a dwell time of $100 \mathrm{~ms}$.

The mass titration method of Noh and Schwarz [31] was used to estimate the point of zero charge (PZC) of the carbon surfaces, at which the net total (external and internal) surface charge of the carbon particles is zero. This is based on the fact that the $\mathrm{pH}$ of the solution changes in the direction 


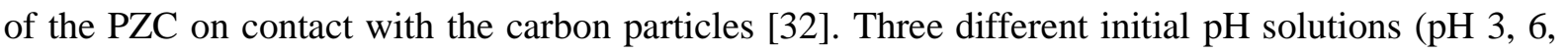
11) were prepared using $\mathrm{HNO}_{3}(0.1 \mathrm{M})$ and $\mathrm{NaOH}(0.1 \mathrm{M})$. Sodium nitrate was used as the background electrolyte. For each initial $\mathrm{pH}$, six containers were filled with $20 \mathrm{ml}$ of the solution and different amounts of carbon were added $(0.05,0.10,0.50,1.00$ and $10 \%$ by weight). The equilibrium $\mathrm{pH}$ was measured after 24 hours. The plot of $\mathrm{pH}$ vs. mass fraction showed a plateau and the PZC is identified as the point at which the change in $\mathrm{pH}$ was negligible. The PZC was then taken as the average of the three asymptotic $\mathrm{pH}$ values.

Temperature-programmed desorption (TPD) experiments were carried out in a vertical tube furnace using $\operatorname{Ar}\left(80 \mathrm{ml} \mathrm{min}^{-1}\right)$ as the carrier gas. A $0.5 \mathrm{~g}$ sample was placed in a quartz tube, heated to 110 ${ }^{\circ} \mathrm{C}$ and held for $60 \mathrm{~min}$ and then ramped at $5{ }^{\circ} \mathrm{C} \min ^{-1}$ to $900{ }^{\circ} \mathrm{C}$. The gases evolved were analysed using a gas chromatograph (Shimadzu GC-17A) equipped with a thermal conductivity detector and a Carbosphere column.

\subsection{Evaluation of carbon fuels in the DCFC}

A schematic diagram of DCFC is shown in Fig.1, which is similar to that of Vutetakis et al. [11, 12]. The working electrode (WE) consisted typically of a solid gold rod (serving as the electrode and current collector, $99.9 \%$ purity, $3.2 \mathrm{~mm}$ diameter) cemented to the end of an alumina tube. A gold wire was spot-welded to the gold rod and extended to the other end of the alumina tube for external contact. The total exposed surface of gold rod was $3.0 \mathrm{~cm}^{2}$. The counter electrode (CE) was made from a gold sheet (with $1.0 \mathrm{~cm}^{2}$ surface area) spot-welded to a gold wire, and the gold parts were sheathed in a $12 \mathrm{~mm}$ diameter closed-bottom alumina tube. A $1.5 \mathrm{~mm}$ hole at the bottom of the alumina sheath allowed contact through the electrolyte between the CE and WE. The reference electrode (RE) was constructed from an alumina sheath (12 mm diameter) containing a gold wire in contact with the electrolyte melt, and a $0.1 \mathrm{~mm}$ pin hole at the bottom of the alumina sheath offered the contact of electrolyte between the RE and WE. The particulate carbon fuels with the ternary molten carbonate electrolytes $(32 \% \mathrm{Li}-34 \% \mathrm{Na}-34 \% \mathrm{~K}$ eutectic) were contained in an alumina crucible. In order to keep entire cell in a gas-tight environment, the alumina crucible was placed at the bottom of an inconel canister and sealed by a water-cooled brass lid. The three electrodes and 
gas feed tubes were supported by the brass lid and inserted into the WE anode compartment. An inconel stirring rod with a half circle impeller and a type-K thermocouple were also placed in the molten carbonate electrolyte.

Prior to each experiment, the dried $250 \mathrm{~g}$ ternary carbonate powder was mixed to a certain concentration (typically 1, 5 and $10 \%$ by weight) of carbon fuel powder. The gold parts of three different electrodes were washed by aqua regis for 10 seconds and rinsed with distilled water followed by acetone. After the fuel cell was assembled and sealed gastight, it was heated by a crucible furnace (Lindberg Blue/M) with heating rate of $3{ }^{\circ} \mathrm{C} \mathrm{min}^{-1}$. During the heat-up stage, the $\operatorname{Ar}\left(150 \mathrm{ml} \mathrm{min}^{-1}\right)$ was purged into the WE compartment and $\mathrm{CO}_{2}\left(50 \mathrm{ml} \mathrm{min}^{-1}\right)$ was purged into the $\mathrm{CE}$ and RE compartments. Once the required operating temperature was reached, the $\mathrm{Ar}$ and $\mathrm{CO}_{2}$ purge rates were decreased to $50 \mathrm{ml} \mathrm{min}^{-1}$ and $14 \mathrm{ml} \mathrm{min}^{-1}$, respectively. At same time, air (35ml $\min ^{-1}$ ) was introduced into the CE and RE compartments. Finally, the carbon anode half-cell measurements were performed with a potentiostat (Autolab PGSTAT302), using the GPES and FRA software package (Version 4.9). For the linear sweep voltammetry measurements, the anodic polarization started from the open circuit voltage $(\mathrm{OCV})$ to the $0.0 \mathrm{~V}$ (relative to $\mathrm{RE}$ ) at scan rate of $1 \mathrm{mV} \mathrm{s}^{-1}$. Note that under open circuit conditions, the potential of the reference electrode is the same as the cathode and therefore the potential difference between the anode and reference is taken as the OCV. In the on-line measurements of anodic product gases (evolved from the WE), the gas flow rate was measured by a soap film burette, and the gas compositions were analysed by a gas chromatography (SHIMADZU GC-8A) with $\mathrm{H}_{2}$ as the carrier gas.

\section{Results}

\subsection{XRD characterizations of carbon fuels}

Figs. 2 and 3 show the XRD patterns of $\mathrm{AC}$ and $\mathrm{CB}$ before and after surface treatments $\left(\mathrm{HNO}_{3}, \mathrm{HCl}\right.$ and air plasma). Only slight changes occurred in the XRD patterns for both AC and CB after various treatments. The asymmetrical (002) peak can be observed at around 24 degrees $2 \theta$ in all carbon fuels. Another weak and broad peak at around 44 degrees $2 \theta$ is attributed to the (100) graphite crystal face reflection. 
The quantitative crystallite parameters of all carbon fuels are summarized in Table 1, including interplanar spacings $\left(\mathrm{d}_{002}\right)$, the average crystallite diameter $(\mathrm{La})$ and the average crystallite stacking height (Lc). Acid treatments with $\mathrm{HNO}_{3}$ and $\mathrm{HCl}$ led to an increase in both $\mathrm{La}$ and Lc crystallite size parameters and decreases in the $\mathrm{d}_{002}$ values corresponding to decreases in the lattice parameter along the c-axis of the unit cell. However, $\mathrm{HNO}_{3}$ seems to be more effective in increasing the crystallite sizes in the carbon fuels compared to an $\mathrm{HCl}$ treatment. These results confirm that an acid treatment can increase the carbon aggregation and degree of graphitic structure to a certain extent [23]. Interestingly, an air plasma treatment has the most significant effect on the carbon crystallite structure as shown in the last row of Table 1. The observed La value of CB-Plasma increases from $2.9 \mathrm{~nm}$ to $4.6 \mathrm{~nm}$ with the $\mathrm{d}_{002}$ decreasing from $0.368 \mathrm{~nm}$ to $0.361 \mathrm{~nm}$, which may be caused by burning off of disordered carbon in CB during the air plasma treatment $[24,25]$.

\subsection{Electrical conductivity of carbon fuels}

Electrical conductivity of the carbon fuel is a critical factor governing DCFC performance, since carbon fuels will not only be consumed in the electrochemical reaction, but will also be contacted with the current collector to transfer directly the electrons [2]. The electrical conductivity is highly dependent on the degree of graphitic structure with the fuel carbons. Usually, a higher degree of graphitic structure leads to a higher electrical conductivity. The bulk conductivity values of the two groups of carbon fuels are listed in column 6 of Table 1. After acid and air plasma treatments, the conductivities of $\mathrm{AC}$ and $\mathrm{CB}$ are improved slightly. Particularly, CB-Plasma shows the highest conductivity $\left(1.72 \mathrm{~S} \mathrm{~cm}^{-1}\right)$ in all carbon fuels, which is correlated with its highest degree of graphitic structure in of all of the carbon fuels. Surprisingly, the AC series provided much lower conductivity than the $\mathrm{CB}$ series. This is probably caused by the air existing in highly porous AC series samples (even though the carbons were pressed into small pellets under pressure) and the air increased the electrical resistance in the conductivity tests.

\subsection{Textural properties of carbon fuels}

The nitrogen adsorption isotherms of $\mathrm{AC}, \mathrm{AC}-\mathrm{HNO}_{3}$ and $\mathrm{AC}-\mathrm{HCl}$ are shown in Fig.4. These $\mathrm{AC}$ 
samples present typical type-I isotherms indicative of highly microporous structures. However, the appearance of hysteresis loops in the isotherms implies the existence of a mesoporous structure. The BET surface areas and pore structures of the three AC samples are presented in Table 2. Compared with untreated $\mathrm{AC}$, the surface area and pore volume of $\mathrm{AC}-\mathrm{HNO}_{3}$ and $\mathrm{AC}-\mathrm{HCl}$ have hardly changed, as shown in the rows 1-3 of Table 2 . It was reported that $\mathrm{HNO}_{3}$ treatment may show a stronger effect on the textural changes of $\mathrm{AC}$ than $\mathrm{HCl}$ treatment due to the fixation of surface oxygen complexes at the entrance of micro-pores, or the collapse of some pore walls by the $\mathrm{HNO}_{3}$ treatments [26, 27]. This is not obvious in our study since $\mathrm{HNO}_{3}$ has a larger effect on the pore structure of AC but less effect on that of $\mathrm{CB}$ as shown in Table 2.

Fig.5 compares the $\mathrm{N}_{2}$ adsorption isotherms of $\mathrm{CB}$ samples before and after different treatments. All of the CB samples principally showed the type-IV characteristic, with a hysteresis loop starting from medium relative pressures and closing at $\mathrm{P} / \mathrm{P}_{0} \approx 1$. The derived values of BET surface area, total pore volume and average pore diameter of these CB samples are summarized in the rows 4-7 of Table 2. The increase of specific surface area and pore volume can be clearly observed when CB is treated with acid and air plasma, which is probably attributed to the removal of ash or organics in CB particles $[25,28]$.

\subsection{Chemical reactivity of carbon fuels in TGA}

Fig.6 shows the weight loss curves of $\mathrm{AC}, \mathrm{AC}-\mathrm{HNO}_{3}$ and $\mathrm{AC}-\mathrm{HCl}$ in air by TGA tests. For all three samples, a small amount of weight loss can be observed below $100{ }^{\circ} \mathrm{C}$ due to desorption of water. The oxidation of carbonaceous species is observed over the range from $450{ }^{\circ} \mathrm{C}$ to $700{ }^{\circ} \mathrm{C}$. For $\mathrm{AC}-\mathrm{HNO}_{3}$, there is another small amount of weight loss below $450{ }^{\circ} \mathrm{C}$ owing to the decomposition of surface functional groups. It is known that the presence of a large amount of surface oxygen functional groups may lead to carbon materials that are highly reactive, thereby decreasing the thermal stability of $\mathrm{AC}-\mathrm{HNO}_{3}$ in TPO tests [27, 29]. For $\mathrm{AC}-\mathrm{HCl}$, the onset of oxidation starts around $550{ }^{\circ} \mathrm{C}$, which is slightly lower than that of $\mathrm{AC}\left(600{ }^{\circ} \mathrm{C}\right)$. The thermal stability of three carbon fuels is of such an order $\mathrm{AC}>\mathrm{AC}-\mathrm{HCl}>\mathrm{AC}-\mathrm{HNO}_{3}$. 
Fig.7 shows the weight loss of $\mathrm{CB}$ series before and after various treatments. Compared with AC, weight loss of physisorbed water below $100{ }^{\circ} \mathrm{C}$ for $\mathrm{CB}$ is much less. The onset of oxidation of as-received $\mathrm{CB}$ is observed from $550^{\circ} \mathrm{C}$. Similar to the acid treatment of $\mathrm{AC}$ samples, $\mathrm{CB}-\mathrm{HNO}_{3}$ and $\mathrm{CB}-\mathrm{HCl}$ are more readily oxidized than untreated $\mathrm{CB}$. For $\mathrm{CB}-\mathrm{HNO}_{3}$, the extensive weight loss starts from $500{ }^{\circ} \mathrm{C}$ and ends around $600{ }^{\circ} \mathrm{C}$, which correlates with the burn-off of carbonaceous species. Below $500{ }^{\circ} \mathrm{C}$, there is another small amount of weight loss in $\mathrm{CB}-\mathrm{HNO}_{3}$ owing to the decomposition of surface functional groups. For $\mathrm{CB}-\mathrm{HCl}$, the onset of oxidation lies around $550^{\circ} \mathrm{C}$, which is slightly lower than that of original CB. However, CB-Plasma had the best oxidation resistance in all carbon black samples, which may be caused by it having the highest graphitic degree as shown in Table1.

\subsection{Surface properties of carbon fuels}

Table 3 shows the atomic concentration of carbon and oxygen on the carbon fuels surface obtained by survey scans in XPS. The ratio of total $\mathrm{O}$ to $\mathrm{C}(\mathrm{O} / \mathrm{C})$ is indicative of the degree of surface oxidation of carbon fuel. In general, all treated carbon fuels showed an increase in the surface oxygen content as expected. However, the $\mathrm{HNO}_{3}$ treated carbon fuels $\left(\mathrm{AC}-\mathrm{HNO}_{3}\right.$ and $\left.\mathrm{CB}-\mathrm{HNO}_{3}\right)$ show the highest oxygen content in all of the carbon samples. Furthermore, the AC series presented higher surface oxygen contents than the CB series under the same treatment probably owing to the different microstructures and textual properties.

In order to further confirm the extent of oxidation of different carbon fuels, the point of zero charge (PZC) values of all carbon fuels (determined by mass titration method) are shown in the last column

of Table 3. The as-received AC and CB carbons showed PZC values of 10.04 and 8.23, respectively. These PZC values diminish after a variety of treatments. Especially, the samples treated with $\mathrm{HNO}_{3}$ had the lowest PZC values, in agreement with previous reports [30] that $\mathrm{HNO}_{3}$ treatment could increase the amounts of the acidic carboxyl and lactone surface groups. However, the PZC of CB-Plasma is only slightly lower than $\mathrm{CB}$, which indicates the air plasma treatment did not change the surface properties of CB substantially. It is known that the more oxidized carbon usually has the 
lower the PZC value [31]. The order of the amount of oxygen on the surface of for the AC series is $\mathrm{AC}-\mathrm{HNO}_{3}>\mathrm{AC}-\mathrm{HCl}>\mathrm{AC}$. For the CB series, the oxygen amount on the surface is of the order $\mathrm{CB}-\mathrm{HNO}_{3}>\mathrm{CB}-\mathrm{HCl}>\mathrm{CB}-\mathrm{Plasma}>\mathrm{CB}$.

Fig.8 presents the $\mathrm{CO}_{2}$ and $\mathrm{CO}$ evolution profiles with increasing temperature from the surfaces of three activated carbons fuels. As expected, $\mathrm{AC}$ with $\mathrm{HNO}_{3}$ treatment generates intense oxygen functional groups on the carbon that leads to the production of the largest amounts of $\mathrm{CO}_{2}$ and $\mathrm{CO}$ in the $\mathrm{Ar}$ gas stream. In contrast, the samples $\mathrm{AC}-\mathrm{HCl}$ and $\mathrm{AC}$ have comparably lower evolution of $\mathrm{CO}_{2}$ and $\mathrm{CO}$ complexes, and different thermal stabilities. In the $\mathrm{CO}_{2}$ evolution spectra, the $\mathrm{AC}-\mathrm{HNO}_{3}$ presents double peaks around $275^{\circ} \mathrm{C}$ and $400{ }^{\circ} \mathrm{C}$. $\mathrm{AC}-\mathrm{HCl}$ and $\mathrm{AC}$ have a single broad peak in the range $200-400{ }^{\circ} \mathrm{C}$, but $\mathrm{AC}-\mathrm{HCl}$ shows a maximum around $270{ }^{\circ} \mathrm{C}$. These results indicate that the $\mathrm{AC}-\mathrm{HNO}_{3}$ has a larger number of carboxyl and lactone surface functional groups than the other two carbon samples, in agreement with the results of PZC and XPS. From the CO evolution curves, the two acid treated AC samples seem to have more active CO complexes than untreated $\mathrm{AC}$, since $\mathrm{AC}-\mathrm{HNO}_{3}$ and $\mathrm{AC}-\mathrm{HCl}$ present peaks at $770{ }^{\circ} \mathrm{C}$ and $820{ }^{\circ} \mathrm{C}$, respectively, while the desorbed $\mathrm{CO}$ concentration on AC was still increasing at $900{ }^{\circ} \mathrm{C}$.

Fig. 9 shows the TPD profiles of CB before and after the different surface treatments. Compared with original $\mathrm{CB}$, the treated $\mathrm{CB}$ samples present an increase in the amount of surface oxygen functional groups, which is evidenced by the increase of the $\mathrm{CO}_{2}$ and $\mathrm{CO}$ peak heights and areas. Especially for $\mathrm{CB}-\mathrm{HNO}_{3}$, the evolution of $\mathrm{CO}_{2}$ shows the sharpest peak at $250{ }^{\circ} \mathrm{C}$ and a shoulder around $425{ }^{\circ} \mathrm{C}$, with the $\mathrm{CO}$ desorption peaks at $700{ }^{\circ} \mathrm{C}$. In comparison, the $\mathrm{CB}-\mathrm{HCl}$ and CB-Plasma samples have much lower evolution of $\mathrm{CO}_{2}$ than $\mathrm{CB}-\mathrm{HNO}_{3}$. CB-Plasma has more stable $\mathrm{CO}_{2}$-yielding surface complexes than $\mathrm{CB}-\mathrm{HCl}$. From the $\mathrm{CO}$ evolution spectra, $\mathrm{CB}$-Plasma shows slightly lower evolution than $\mathrm{CB}-\mathrm{HCl}$ from 400 to $900{ }^{\circ} \mathrm{C}$. This further confirms that the CB-Plasma has less total surface oxygen functional groups compared to $\mathrm{CB}-\mathrm{HCl}$ and $\mathrm{CB}-\mathrm{HNO}_{3}$.

In general, the $\mathrm{HNO}_{3}$ treatment results in large amounts of $\mathrm{CO}_{2}$-yielding functional groups on the surface of $\mathrm{AC}$ and $\mathrm{CB}$. On the other hand, an $\mathrm{HCl}$ treatment lowers the stability of CO-yielding 
surface groups on the carbon surface, which can thus be desorbed at a lower temperature in the TPD tests. Air plasma treatment has a similar effect on the carbon surface as the $\mathrm{HCl}$ treatment.

\subsection{Electrochemical reactivity of carbon fuels in DCFC}

Fig. 10 presents the anodic polarization curves of $5 \% \mathrm{AC}, \mathrm{AC}-\mathrm{HNO}_{3}$ and $\mathrm{AC}-\mathrm{HCl}$ at $700^{\circ} \mathrm{C}$ with 600 rpm stirring condition. The polarization curves of the three AC carbon fuels are similar in shape. The curves all drop steeply from OCV to around $-0.8 \mathrm{~V}$ due to the activation resistance. Following that, a more stable linear region appears from $-0.8 \mathrm{~V}$ to $-0.4 \mathrm{~V}$, which indicates that anodic polarization is under significant ohmic resistance control. Finally, the potential decreases sharply at high current density as fuel is consumed faster than it is supplied to the electrode, which is known as a mass transport limitation. In these three carbon fuels, the $\mathrm{AC}-\mathrm{HNO}_{3}$ shows the highest electrochemical reactivity, since it has the highest current density at a given potential. Although AC and $\mathrm{AC}-\mathrm{HCl}$ have comparably low electrochemical reactivities in the DCFC, the latter shows a higher current density than the former in the low over-potential region (from OCV to $-0.8 \mathrm{~V}$ ). It is known that the current densities in the low over-potential region are dominated by the rates of the relevant electrochemical reactions. These results indicate that acid treatments $\left(\mathrm{HNO}_{3}\right.$ and $\left.\mathrm{HCl}\right)$ of AC can improve the electrochemical reaction rates effectively.

Table 4 provides a detailed comparison of the OCV and current density (I) at given potentials and specific area resistance (Rs) of $\mathrm{AC}, \mathrm{AC}-\mathrm{HNO}_{3}$ and $\mathrm{AC}-\mathrm{HCl}$. The $\mathrm{OCV}$ values of the three carbon fuels are similar at the same temperature, and they all become more negative when the temperature increases from $600{ }^{\circ} \mathrm{C}$ to $800{ }^{\circ} \mathrm{C}$. This change in the OCV is caused by the shift of anodic electrochemical equilibrium as discussed by other researchers [7, 9-12, 17]. Under the same experimental conditions, $\mathrm{AC}-\mathrm{HNO}_{3}$ always shows the highest current density of the three carbon fuels, which means that $\mathrm{AC}-\mathrm{HNO}_{3}$ has the faster discharge rate than the other carbons. $\mathrm{AC}-\mathrm{HCl}$ and AC show comparably lower current densities (especially from the medium to higher over-potential regions). Rs is the slope of the anodic voltage versus the current density in the linear central region of polarization curve [14], and is a measurement for the global ohmic resistance which comes from the carbon fuels and electrolytes, the electrode materials, and even the mechanical connections 
within the cell apparatus. The Rs values at $600{ }^{\circ} \mathrm{C}$ are much higher than those at $700{ }^{\circ} \mathrm{C}$ and $800{ }^{\circ} \mathrm{C}$ since the electrical conductivity of molten carbonate increases significantly with increasing temperature $[11,12,19]$. At the same temperature, $\mathrm{AC}-\mathrm{HNO}_{3}$ has the lowest Rs value in three carbon samples, which correlates with it having the highest electrical conductivity, as shown in Table 1. On the whole, the electrochemical reactivities of the three AC carbon fuels are in the order $\mathrm{AC}<\mathrm{AC}-\mathrm{HCl}<\mathrm{AC}-\mathrm{HNO}_{3}$.

Fig.11 presents the anodic polarization curves of the four $\mathrm{CB}$ carbon fuels at $700^{\circ} \mathrm{C}$ with $600 \mathrm{rpm}$ stirring conditions. Similarly, these carbon fuels all display typical three-phase regime polarization curves to the AC carbon fuels, which can be attributed to the activation polarization, ohmic polarization and concentration polarization regimes, respectively. The $\mathrm{CB}-\mathrm{HNO}_{3}$ shows the highest current density or the highest electrochemical reactivity. Although the $\mathrm{CB}, \mathrm{CB}-\mathrm{HCl}$ and $\mathrm{CB}-\mathrm{Plasma}$ have similar low values in the Ohmic region of the polarization curves, the treated CB fuels (CB-HCl and CB-Plasma) show higher current densities than the untreated $\mathrm{CB}$ at both activation and concentration regions. This indicates the acid and plasma treatments can improve the CB electrochemical reaction rate to different extents.

Table 5 provides a comparison of OCV, current density (I) at given potentials, specific area resistance (Rs) of the $\mathrm{CB}$ series of carbon fuels. Compared with the $\mathrm{AC}$ series, these four $\mathrm{CB}$ carbon fuels have much lower current densities at the same given potentials, indicating that the CB series are less active in the DCFC reaction. However, the discharge rate of $\mathrm{CB}$ can effectively be increased by acid and air plasma treatments, which is similar to the AC carbon fuels. Especially with the $\mathrm{HNO}_{3}$ treatment, the current density of $\mathrm{CB}-\mathrm{HNO}_{3}$ is 2-3 times higher than that of original $\mathrm{CB}$. This is consistent with altered microstructure and surface properties of $\mathrm{CB}-\mathrm{HNO}_{3}$, which will be addressed in detail in Section 4. However, the $\mathrm{HCl}$ and air plasma pre-treated $\mathrm{CB}$ had a lower electrochemical reactivity than $\mathrm{CB}-\mathrm{HNO}_{3}$. Interestingly, the $\mathrm{CB}-\mathrm{Plasma}$ shows the lowest Rs value that may be caused by it having the highest electrical conductivity of all the carbon samples (see Table 1). In general, the electrochemical reactivities of the four $\mathrm{CB}$ carbon fuels increase in the order of: $\mathrm{CB}<\mathrm{CB}-\mathrm{HCl} \approx \mathrm{CB}-\mathrm{Plasma}<\mathrm{CB}-\mathrm{HNO}_{3}$. 


\subsection{Anodic off-gas analysis}

In order to study the anodic electrode kinetics, Table 6 compares the gas evolution data from the WE compartment using 5wt\% $\mathrm{AC}, \mathrm{AC}-\mathrm{HNO}_{3}$ and $\mathrm{AC}-\mathrm{HCl}$ at 600,700 and $800{ }^{\circ} \mathrm{C}$ with $600 \mathrm{rpm}$ stirring. In the second column of Table 6, the off-gas composition was analysed by gas chromatography (GC) with the current off to give a baseline, and then with the current on to measure the gases produced by the electrochemical reaction. Only the purge gas Ar and carbon oxides $\left(\mathrm{CO}\right.$ and $\left.\mathrm{CO}_{2}\right)$ were found at measurable levels in the $\mathrm{GC}$ analysis. The $\mathrm{CO}$ concentration increased with rising cell temperature; however, the $\mathrm{CO}_{2}$ concentration increased slightly from 600 ${ }^{\circ} \mathrm{C}$ to $700{ }^{\circ} \mathrm{C}$, and decreased sharply at $800^{\circ} \mathrm{C}$. This phenomenon may be caused by the Boudouard reaction (7), which can easily occur at temperatures above $750^{\circ} \mathrm{C}[9,12,33]$ :

$\mathrm{CO}_{2}(\mathrm{~g})+\mathrm{C}(\mathrm{s})=2 \mathrm{CO}(\mathrm{g})$

The net electrochemical $\mathrm{CO}_{2}$ evolution rate $\left(\mathrm{Q}_{\mathrm{CO} 2}\right)$ was calculated by the difference between the outlet $\mathrm{CO}_{2}$ flow rate with current on and the $\mathrm{CO}_{2}$ flow rate with current off, as in Eq. (8) [12]:

$\mathrm{Q}_{\mathrm{CO} 2}=\left(\mathrm{X}_{\mathrm{CO} 2} \mathrm{Q}_{\mathrm{Total}}\right)_{\mathrm{I}-\mathrm{on}}-\left(\mathrm{X}_{\mathrm{CO} 2} \mathrm{Q}_{\text {Total }}\right)_{\mathrm{I} \text {-off }}$

Consequently, the electrochemical $\mathrm{CO}_{2}$ yield $\left(\mathrm{Y}_{\mathrm{CO} 2}\right)$ can be calculated by $\mathrm{Eq}(9)$ [12]:

$$
Y_{\mathrm{CO} 2}=\frac{Q_{\mathrm{CO} 2} F}{V_{m} I}
$$

where $\mathrm{F}$ is Faraday constant (96485 Coulomb/mole), $\mathrm{V}_{\mathrm{m}}$ is the molar volume of $\mathrm{CO}_{2}$ at $300 \mathrm{~K} 1 \mathrm{~atm}$ ( $\mathrm{ml} / \mathrm{mole})$ and $\mathrm{I}$ is the current applied in the gas measurements (A). Similarly, the total electrochemical product gas evolution rate $\left(\mathrm{Q}_{(\mathrm{CO} 2+\mathrm{CO})}\right)$ and gas yield $\left(\mathrm{Y}_{(\mathrm{CO} 2+\mathrm{CO})}\right)$ can be calculated with Eq.s (10) and (11) [12]:

$$
\begin{aligned}
& \mathrm{Q}_{(\mathrm{CO} 2+\mathrm{CO})}=\left[\left(\mathrm{X}_{\mathrm{CO} 2}+\mathrm{X}_{\mathrm{CO}}\right) \mathrm{Q}_{\text {Total }}\right]_{\mathrm{I}-\mathrm{on}}-\left[\left(\mathrm{X}_{\mathrm{CO} 2}+\mathrm{X}_{\mathrm{CO}}\right) \mathrm{Q}_{\mathrm{Total}}\right]_{\mathrm{I}-\mathrm{off}} \\
& Y_{(\mathrm{CO} 2+\mathrm{CO})}=\frac{Q_{(\mathrm{CO} 2+\mathrm{CO})} F}{V_{m} I}
\end{aligned}
$$

As shown in the Table 6 , the $\mathrm{Y}_{\mathrm{CO} 2}$ is around $0.6-0.75$, and $\mathrm{Y}_{(\mathrm{CO} 2+\mathrm{CO})}$ ranges between $0.65-0.8$ for 
these three $\mathrm{AC}$ samples at $600^{\circ} \mathrm{C}$ and $700^{\circ} \mathrm{C}$, in agreement with the theoretical $\mathrm{CO}_{2}$ yield of 0.75 in the assumed main anodic reaction as shown in Eq (1).This indicates that the main product of the electrochemical oxidation of carbon at $600-700^{\circ} \mathrm{C}$ is $\mathrm{CO}_{2}$ rather than $\mathrm{CO}$, consistent with previous reports $[11,12]$. However, the $\mathrm{Y}_{\mathrm{CO} 2}$ decreases to $0.28-0.46$ and $\mathrm{Y}_{(\mathrm{CO} 2+\mathrm{CO})}$ increases to 0.95-1.03 when the temperature rises to $800^{\circ} \mathrm{C}$. This may be caused by the Boudouard reaction (7), which consumes the formed $\mathrm{CO}_{2}$ and carbon fuels at higher temperature. Alternatively, the electrochemical oxidation of carbon at $800^{\circ} \mathrm{C}$ may be explained by the reaction $(12)[33,34]$ :

$\mathrm{C}(\mathrm{s})+\mathrm{CO}_{3}{ }^{2-}=\mathrm{CO}_{2}(\mathrm{~g})+\mathrm{CO}(\mathrm{g})+2 \mathrm{e}^{-}$

where the theoretical value of total gas evolution $\left(\mathrm{CO}_{2}\right.$ and $\left.\mathrm{CO}\right)$ is 1.0. Under the same operational conditions, the $\mathrm{AC}-\mathrm{HNO}_{3}$ presents the highest $\mathrm{Q}_{\mathrm{CO} 2}$ and $\mathrm{Y}_{\mathrm{CO} 2}$ values in these three carbon fuels which means more $\mathrm{AC}-\mathrm{HNO}_{3}$ fuels participated in the electrochemical oxidation in the DCFC due to their highest reactivities.

The carbon efficiency $\left(\mathrm{E}_{\text {Carbon }}\right)$ shown in Fig. 12, which evaluates the ratio of electrochemical oxidation of carbon via Eq. (1) to total carbon consumption (chemical and electrochemical), is calculated by Eq. (13) [12]:

$E_{\text {Carbon }}=\frac{(1 / 3) Q_{\mathrm{CO} 2}}{(1 / 2)\left(X_{C O} Q_{\text {Total }}\right)_{I-o n}+(1 / 3) Q_{C O 2}} \times 100 \%$

where the coefficients are determined by the molar ratios of the gas products to one mole of reactant carbon consumed in Eq.s (1) and (7), respectively.

It can be seen that the $\mathrm{E}_{\text {Carbon }}$ values decrease with an increase in the temperature, due to the parasitic chemical loss of carbon by the Boudouard reaction (7) at higher temperature. Especially at $800{ }^{\circ} \mathrm{C}$, the $\mathrm{E}_{\text {Carbon }}$ is less than $10 \%$, which means more than $90 \%$ of carbon fuels were heavily consumed by the chemical rather than electrochemical reaction. Interestingly, at the same temperature, the treated carbon fuels $\left(\mathrm{AC}-\mathrm{HNO}_{3}\right.$ and $\left.\mathrm{AC}-\mathrm{HCl}\right)$ presented slightly higher carbon efficiencies than untreated $\mathrm{AC}$, especially for the $\mathrm{AC}-\mathrm{HNO}_{3}$. These results further confirm the 
improvement of electrochemical reactivity for acid treated carbon fuels.

\section{Discussion}

Although the electrochemical oxidation of carbon fuels in the present investigation occurs in the heterogeneous carbon-carbonate and electrode-carbonate interfaces, the basic mechanism of carbon oxidation in molten carbonate is similar to the reactions of carbon with oxygen containing gases. It is well known that the carbon properties, such as degree of graphitic structure, surface area, pore structure, particle size and the surface property can influence the reaction of carbon gasification in oxygen. In the process of carbon oxidation, molecular oxygen dissociatively chemisorbs onto reactive carbon sites to form surface oxygen functional groups, and decomposes to form $\mathrm{CO}_{2}$ and/or $\mathrm{CO}$ upon reaction. As a result of the removal of carbon atoms, new free reactive sites are exposed for subsequent chemisorption $[35,36]$. Therefore, the number of surface oxygen functional groups plays a key role in carbon gasification reactions.

In our study, the improvement of electrochemical reactivity of treated $\mathrm{AC}$ and $\mathrm{CB}$ can be explained by dramatic changes in their surface properties after different treatments. Especially, the $\mathrm{HNO}_{3}$ treated carbon fuels $\left(\mathrm{AC}-\mathrm{HNO}_{3}\right.$ and $\left.\mathrm{CB}-\mathrm{HNO}_{3}\right)$ present much higher electrochemical reactivity than the other carbon fuels in the DCFC, which is mainly caused by the presence of high amounts of surface oxygen functional groups. As shown by the study of surface chemical properties (Section 3.5), the $\mathrm{HNO}_{3}$ treated carbon fuels have the highest number of oxygen groups, which can be converted into a large number of free reactive sites. This is the major contribution for the enhanced anodic discharge rate in the DCFC tests. Meanwhile, the Rs of DCFC is decreased by using the $\mathrm{HNO}_{3}$ treated carbon fuels, which may be attributed to an increase of their degree of graphitic structure. This may also be helpful for the performance of $\mathrm{HNO}_{3}$-treated carbons, but its contribution may be limited. The $\mathrm{HCl}$ and air plasma treated carbon fuels showed lower electrochemical reactivities than the $\mathrm{HNO}_{3}$ treated carbons. As mentioned above, the quantity of surface oxygen functional groups directly affects the electrochemical discharge rate of carbon fuels. For $\mathrm{HCl}$ and air plasma treated carbons, they have much less surface oxygen functional groups compared with $\mathrm{HNO}_{3}$ treated carbons as shown in TPD and XPS studies. CB-Plasma shows lower 
Rs value than $\mathrm{CB}-\mathrm{HCl}$, which may be attributed to the highest degree of graphitic structure with CB-Plasma. Compared with AC carbons, CB carbons are much less reactive in the DCFC. This may be attributed primarily to the former's enhanced surface area, which provides more contact between the carbon fuels and the electrolytes.

\section{Conclusion}

Two groups of commercial carbon fuels (CB and $\mathrm{AC}$ ) with different surface modifications were evaluated in a DCFC system. The $\mathrm{HNO}_{3}$ treatment can dramatically improve the electrochemical reactivity of carbon fuels in the DCFC due to an enhancement in oxygen-containing surface functional groups, which in turn may produce high amounts of active sites by desorption. The air plasma treatment has the greatest effect on the degree of graphitic structure of the carbon. The overall effect on changing the electrochemical reactivity of carbon fuels is of the order $\mathrm{HNO}_{3}>$ air

plasma $\approx \mathrm{HCl} . \mathrm{HNO}_{3}$ treated activated carbon, $\mathrm{AC}-\mathrm{HNO}_{3}$, shows the highest current density (240 $\mathrm{mA} \mathrm{cm}^{-2}$ at $\left.-0.3 \mathrm{~V}\right)$. The complete oxidation of carbon to $\mathrm{CO}_{2}$ can be achieved at $600-700{ }^{\circ} \mathrm{C}$, while and carbon is partially electrochemically oxidised to $\mathrm{CO}$ at $800{ }^{\circ} \mathrm{C}$.

\section{Acknowledgment}

Financial Support from ARC (Australian Research Council) discovery project is greatly appreciated. 


\section{References}

[1] D. Cao, Y. Sun, G. Wang, Journal of Power Sources, 167 (2) (2007), $250-7$.

[2] N. J. Cherepy, R. Krueger, K. J. Fiet, A.F. Jankowski, J.F. Cooper, Journal of the Electrochemical Society, 152(1) (2005), A80-A7.

[3] J. F. Cooper, Proceedings of the Second International Conference on Fuel Cell Science, Engineering and Technology, Rochester, NY, United States, June 14-16, 2004, p375-85.

[4] J.F. Cooper, N. Cherepy, Carbon fuel particles used in direct carbon conversion fuel cells, US patent 845939, 2004.

[5] J.F. Cooper, R. Krueger, N. Cherepy, A high temperature, molten electrolyte electrochemical cell comprising ash-free turbostratic carbon particles, US patent 970283, 2001

[6] K. Hemmes, M. Cassir, Proceedings of the Second International Conference on Fuel Cell Science, Engineering and Technology, Rochester, NY, United States, June 14-16, 2004, p395-400.

[7] S. Zecevic, E.M. Patton, P. Parhami, Chemical Engineering Communications, 192(10-12) (2005) 1655-70.

[8] J. Dubois, J. Millet, S. Palous, Electrochimica Acta, 12(3) (1967)241-4.

[9] Hauser V. A study of carbon anode polarization in fused carbonate fuel cells. PhD thesis, Oregon State University, Corvallis, OR, USA, 1964.

[10]W.H.A. Peelen, M. Olivry, S.F. Au, J.D. Fehribach, K. Hemmes, Journal of Applied Electrochemistry, 30(12) (2000)1389-95.

[11]D.G..Vutetakis Electrochemical oxidation of carbonaceous materials dispersed in molten carbonate, PhD thesis, Ohio State University, Columbus, OH, USA, 1985.

[12]D.G. Vutetakis, D.R. Skidmore, H.J. Byker, Journal of the Electrochemical Society, 134(12) (1987) 3027-35.

[13]R.D. Weaver, S.C. Leach, L. Nanis, Proceedings of the Intersociety Energy Conversion Engineering Conference, 1981, $16^{\text {th }}$ (Vol. 1), p717-21.

[14] G.A. Hackett, J.W. Zondlo, R. Svensson, Journal of Power Sources, 168(1) (2007) 111-8.

[15]T. Nunoura, K. Dowaki, C. Fushimi, S. Allen, E. Meszaros, M.J. Antal, Industrial \& 
Engineering Chemistry Research, 46(3) (2007) 734-44.

[16]P.V. Pesavento, Carbon-air fuel cell, US patent 6200697, 2001.

[17] S. Zecevic, E.M. Patton, P. Parhami, Carbon, 42(10) (2004) 1983-93.

[18] T.M. Gur, R.A.Huggins, Journal of the Electrochemical Society, 140(7) (1993) 1990-2000.

[19] K. Pointon, B. Lakeman, J. Irvine, J. Bradley, S. Jain, Journal of Power Sources, 162(2) (2006) $750-6$.

[20]A.L.Dicks, Journal of Power Sources, 156(2) ( 2006) 128-41.

[21]K. Kinoshita, Carbon: electrochemical and physicochemical properties. New York: Wiley, 1988.

[22]L. Li, Z.H. Zhu, G.Q. Lu, Z.F. Yan, R. De Marco, Applied Catalysis A-General, 309 (2) (2006) 201-9.

[23] S. Kim, S. J. Park, Electrochimica Acta, 52(9) (2007) 3013-21.

[24]Z. Tang, Q. Li, G. Lu, Carbon, 45(1) (2007) 41-6.

[25] S.J. Park, J.S. Kim, Journal of Colloid and Interface Science, 244(2) (2001) 336-41.

[26] J.L. Figueiredo, M.F.R. Pereira, M.M.A. Freitas, J.J.M.Orfao, Carbon, 37(9) (1999) 1379-89.

[27]B.K. Pradhan, N.K.Sandle, Carbon, 37(8) (1999) 1323-32.

[28] T. Takada, M. Nakahara, H. Kumagai, Y. Sanada, Carbon, 34(9) (1996) 1087-91.

[29]P. Li, T. J. Zhao, J.H. Zhou, Z.J. Sui, Y.C. Dai, W.K. Yuan, Carbon, 43(13) (2005) 2701-10.

[30]Z.H. Zhu, L.R. Radovic, G.Q.Lu. Carbon, 38(3) (2000) 451-64.

[31]J.S. Noh, J.A. Schwarz, Carbon, 28(5) (1990) 675-82.

[32] H. P. Boehm, Carbon, 40(2) (2002), 145-9.

[33] R.D.Weaver, S.C. Leach, A.E. Bayce, L. Nanis, Direct electrochemical generation of electricity from coal, Report for the period 16 May 1977 to 15 February 1979. 1979, SRI, Menlo Park, CA 94025; SAN-0115/105-1.

[34] K. Sasaki, A. Kunai, T. Sada, Denki Kagaku, 48(5) (1980) 311-4.

[35]L.R. Radovic, P.L. Walker Jr, R.G. Jenkins, Fuel, 62(7) (1983) 849-56.

[36] A.A. Lizzio, H. Jiang, L.R. Radovic, Carbon, 28(1) (1990) 7-19. 


\section{List of Figures}

Fig. 1 Schematic diagram of direct carbon fuel cell

Fig. 2 XRD patterns of $\mathrm{AC}, \mathrm{AC}-\mathrm{HNO}_{3}$ and $\mathrm{AC}-\mathrm{HCl}$

Fig. 3 XRD patterns of $\mathrm{CB}, \mathrm{CB}-\mathrm{HNO}_{3}, \mathrm{CB}-\mathrm{HCl}$ and $\mathrm{CB}-\mathrm{Plasma}$

Fig. $4 \mathrm{~N}_{2}$ adsorption isotherms of $\mathrm{AC}, \mathrm{AC}-\mathrm{HNO}_{3}$ and $\mathrm{AC}-\mathrm{HCl}$

Fig. $5 \mathrm{~N}_{2}$ adsorption isotherms of $\mathrm{CB}, \mathrm{CB}-\mathrm{HNO}_{3}, \mathrm{CB}-\mathrm{HCl}$ and $\mathrm{CB}-\mathrm{Plasma}$

Fig.6 TGA curves of $\mathrm{AC}, \mathrm{AC}-\mathrm{HNO}_{3}$ and $\mathrm{AC}-\mathrm{HCl}$

Fig.7 TGA curves of $\mathrm{CB}, \mathrm{CB}-\mathrm{HNO}_{3}, \mathrm{CB}-\mathrm{HCl}$ and $\mathrm{CB}-\mathrm{Plasma}$

Fig.8. TPD profiles of (a) $\mathrm{CO}_{2}$ and (b) $\mathrm{CO}$ from $\mathrm{AC}-\mathrm{HNO}_{3}, \mathrm{AC}-\mathrm{HCl}$ and $\mathrm{AC}$

Fig 9. TPD profiles of (a) $\mathrm{CO}_{2}$ and (b) $\mathrm{CO}$ from $\mathrm{CB}-\mathrm{HNO}_{3}, \mathrm{CB}-\mathrm{HCl}, \mathrm{CB}-\mathrm{Plasma}$ and $\mathrm{CB}$

Fig.10 Polarization curves and of 5\% AC series carbon fuels at $700{ }^{\circ} \mathrm{C}$ with $600 \mathrm{rpm}$ stirring

Fig.11 Polarization curves of 5\% CB series carbon fuels at $700{ }^{\circ} \mathrm{C}$ with $600 \mathrm{rpm}$ stirring

Fig. 12 Carbon efficiency of $5 \% \mathrm{AC}, \mathrm{AC}-\mathrm{HNO}_{3}$ and $\mathrm{AC}-\mathrm{HCl}$ at $600-800{ }^{\circ} \mathrm{C}$ 
Table 1

Crystalline parameters and electrical conductivities of all carbon fuels

\begin{tabular}{ccccc}
\hline \multirow{2}{*}{$\begin{array}{c}\text { Carbon } \\
\text { Fuel }\end{array}$} & \multicolumn{2}{c}{ XRD } & \multicolumn{2}{c}{$\begin{array}{c}\text { Electrical } \\
\text { Conductivity }\end{array}$} \\
\cline { 2 - 5 } Samples & $\mathbf{d}_{\mathbf{0 0 2}}$ & $\mathbf{L}_{\mathbf{c}}$ & $\mathbf{L}_{\mathbf{a}}$ & $\boldsymbol{\sigma}$ \\
$(\mathbf{n m})$ & $(\mathbf{n m})$ & $(\mathbf{n m})$ & $\left.\mathbf{( S ~ c m}^{-1}\right)$ \\
\hline $\mathrm{AC}$ & $0.373(5)$ & $1.0(1)$ & $4.5(3)$ & $0.82(5)$ \\
$\mathrm{AC}-\mathrm{HNO}{ }_{3}$ & $0.353(4)$ & $1.2(1)$ & $4.8(3)$ & $0.88(6)$ \\
$\mathrm{AC}-\mathrm{HCl}$ & $0.356(4)$ & $1.1(1)$ & $4.6(.3)$ & $0.83(5)$ \\
\hline $\mathrm{CB}$ & $0.368(5)$ & $1.5(1)$ & $2.9(2)$ & $1.54(12)$ \\
$\mathrm{CB}-\mathrm{HNO}{ }_{3}$ & $0.356(4)$ & $1.7(2)$ & $3.8(3)$ & $1.69(13)$ \\
$\mathrm{CB}-\mathrm{HCl}$ & $0.363(5)$ & $1.6(2)$ & $3.7(3)$ & $1.59(12)$ \\
$\mathrm{CB}-\mathrm{Plasma}$ & $0.361(5)$ & $1.5(2)$ & $4.6(4)$ & $1.72(14)$ \\
\hline
\end{tabular}

Table 2

Textural properties of all carbon fuels

\begin{tabular}{cccccc}
\hline \multirow{2}{*}{ Carbon } & \multicolumn{5}{c}{$\mathbf{N}_{\mathbf{2}}$ adsorption } \\
\cline { 2 - 6 } Samples & $\begin{array}{c}\mathbf{S}_{\text {BET }} \\
\left(\mathbf{m}^{\mathbf{2}} \mathbf{g}^{-\mathbf{1}}\right)\end{array}$ & $\begin{array}{c}\mathbf{V}_{\text {Total }} \\
\left(\mathbf{c m}^{\mathbf{3}} \mathbf{g}^{-\mathbf{1}}\right)\end{array}$ & $\begin{array}{c}\mathbf{D}_{\text {pore }} \\
(\mathbf{n m})\end{array}$ & $\begin{array}{c}\mathbf{S}_{\text {micro }} \\
\left(\mathbf{m}^{\mathbf{2}} \mathbf{g}^{-\mathbf{1}}\right)\end{array}$ & $\begin{array}{c}\mathbf{V}_{\text {micro }} \\
\left(\mathbf{c m}^{\mathbf{3}} \mathbf{g}^{-\mathbf{1}}\right)\end{array}$ \\
\hline $\mathrm{AC}$ & $1225(123)$ & $0.538(27)$ & $0.88(4)$ & $1193(119)$ & $0.491(25)$ \\
$\mathrm{AC}-\mathrm{HNO}{ }_{3}$ & $1082(108)$ & $0.514(26)$ & $0.91(5)$ & $1018(102)$ & $0.427(21)$ \\
$\mathrm{AC}-\mathrm{HCl}$ & $1204(120)$ & $0.532(26)$ & $0.89(4)$ & $1157(116)$ & $0.473(24)$ \\
\hline $\mathrm{CB}$ & $107(10)$ & $0.243(12)$ & $4.56(24)$ & $9(1)$ & $0.004(1)$ \\
$\mathrm{CB}-\mathrm{HNO}$ & $125(12)$ & $0.482(24)$ & $7.61(38)$ & $16(2)$ & $0.008(1)$ \\
$\mathrm{CB}-\mathrm{HCl}$ & $113(11)$ & $0.351(17)$ & $5.97(30)$ & $7(1)$ & $0.003(1)$ \\
$\mathrm{CB}-\mathrm{Plasma}$ & $136(13)$ & $0.567(28)$ & $8.52(43)$ & $6(1)$ & $0.003(1)$ \\
\hline
\end{tabular}


Table 3

XPS and mass titration analyses of surface properties of all carbon fuels

\begin{tabular}{ccccc}
\hline Samples & O (\%) & $\mathbf{C}(\boldsymbol{\%})$ & O/C & PZC \\
\hline $\mathrm{AC}$ & 8.0 & 90.8 & 0.088 & 10.04 \\
$\mathrm{AC}^{-} \mathrm{HNO}_{3}$ & 10.6 & 88.1 & 0.121 & 3.15 \\
$\mathrm{AC}-\mathrm{HCl}$ & 9.1 & 90.1 & 0.101 & 7.34 \\
\hline $\mathrm{CB}$ & 1.9 & 97.9 & 0.019 & 8.23 \\
$\mathrm{CB}-\mathrm{HNO}$ & 9.3 & 88.9 & 0.105 & 3.35 \\
$\mathrm{CB}-\mathrm{HCl}$ & 5.5 & 93.3 & 0.058 & 4.42 \\
$\mathrm{CB}-\mathrm{Plasma}$ & 2.6 & 97.0 & 0.026 & 8.16 \\
\hline
\end{tabular}


Table 4

Electrochemical data of $\mathrm{AC}, \mathrm{AC}-\mathrm{HNO}_{3}$ and $\mathrm{AC}-\mathrm{HCl}$ at different temperature

\begin{tabular}{|c|c|c|c|c|}
\hline & Conditions & $\mathbf{A C}$ & $\mathrm{AC}_{-} \mathrm{HNO}_{3}$ & $\mathrm{AC}-\mathrm{HCl}$ \\
\hline \multirow{5}{*}{$\begin{array}{l}600{ }^{\circ} \mathrm{C} \\
600 \mathrm{rpm}\end{array}$} & $\mathrm{OCV}(\mathrm{V})$ & -1.02 & -1.05 & -1.03 \\
\hline & I at $-0.9 \mathrm{~V}\left(\mathrm{~mA} \mathrm{~cm}^{-2}\right)$ & 7.7 & 13 & 9.3 \\
\hline & I at $-0.6 \mathrm{~V}\left(\mathrm{~mA} \mathrm{~cm}^{-2}\right)$ & 19 & 40 & 22 \\
\hline & I at $-0.3 \mathrm{~V}\left(\mathrm{~mA} \mathrm{~cm}^{-2}\right)$ & 34 & 55 & 43 \\
\hline & $\operatorname{Rs}\left(\Omega \mathrm{cm}^{-2}\right)$ & 22.7 & 10.2 & 14.3 \\
\hline \multirow{5}{*}{$\begin{array}{l}700{ }^{\circ} \mathrm{C} \\
600 \mathrm{rpm}\end{array}$} & OCV $(\mathrm{V})$ & -1.2 & -1.21 & -1.19 \\
\hline & I at $-0.9 \mathrm{~V}\left(\mathrm{~mA} \mathrm{~cm}^{-2}\right)$ & 14.8 & 35.6 & 21 \\
\hline & I at $-0.6 \mathrm{~V}\left(\mathrm{~mA} \mathrm{~cm}^{-2}\right)$ & 69 & 100 & 68 \\
\hline & I at $-0.3 \mathrm{~V}\left(\mathrm{~mA} \mathrm{~cm}^{-2}\right)$ & 118 & 130 & 124 \\
\hline & $\operatorname{Rs}\left(\Omega \mathrm{cm}^{-2}\right)$ & 4.3 & 4.0 & 5.5 \\
\hline \multirow{5}{*}{$\begin{array}{l}800{ }^{\circ} \mathrm{C} \\
600 \mathrm{rpm}\end{array}$} & $\mathrm{OCV}(\mathrm{V})$ & -1.34 & -1.35 & -1.33 \\
\hline & I at $-0.9 \mathrm{~V}\left(\mathrm{~mA} \mathrm{~cm}^{-2}\right)$ & 36.5 & 86 & 53.5 \\
\hline & I at $-0.6 \mathrm{~V}\left(\mathrm{~mA} \mathrm{~cm}^{-2}\right)$ & 118 & 160 & 132 \\
\hline & I at $-0.3 \mathrm{~V}\left(\mathrm{~mA} \mathrm{~cm}^{-2}\right)$ & 240 & 260 & 208 \\
\hline & $\operatorname{Rs}\left(\Omega \mathrm{cm}^{-2}\right)$ & 2.9 & 2.6 & 3.8 \\
\hline
\end{tabular}


Table 5

Electrochemical data of $\mathrm{CB}, \mathrm{CB}-\mathrm{HNO}_{3}, \mathrm{CB}-\mathrm{HCl}$ and $\mathrm{CB}-\mathrm{Plasma}$ at $700-800{ }^{\circ} \mathrm{C}$

\begin{tabular}{|c|c|c|c|c|c|}
\hline & Conditions & CB & $\mathrm{CB}_{-} \mathrm{HNO}_{3}$ & CB-HCl & CB-Plasma \\
\hline \multirow{5}{*}{$\begin{array}{l}700{ }^{\circ} \mathrm{C} \\
600 \mathrm{rpm}\end{array}$} & $\mathrm{OCV}(\mathrm{V})$ & -1.13 & -1.17 & -1.14 & -1.16 \\
\hline & I at $-0.9 \mathrm{~V}\left(\mathrm{~mA} \mathrm{~cm}^{-2}\right)$ & 7 & 13 & 11 & 9 \\
\hline & I at $-0.6 \mathrm{~V}\left(\mathrm{~mA} \mathrm{~cm}^{-2}\right)$ & 38 & 54 & 35 & 23 \\
\hline & I at $-0.3 \mathrm{~V}\left(\mathrm{~mA} \mathrm{~cm}^{-2}\right)$ & 55 & 83 & 59 & 78 \\
\hline & $\operatorname{Rs}\left(\Omega \mathrm{cm}^{-2}\right)$ & 8.3 & 6.5 & 8.5 & 5.6 \\
\hline \multirow{5}{*}{$\begin{array}{l}800{ }^{\circ} \mathrm{C} \\
600 \mathrm{rpm}\end{array}$} & $\mathrm{OCV}(\mathrm{V})$ & -1.26 & -1.31 & -1.28 & -1.29 \\
\hline & I at $-0.9 \mathrm{~V}\left(\mathrm{~mA} \mathrm{~cm}^{-2}\right)$ & 16 & 46 & 32 & 22 \\
\hline & I at $-0.6 \mathrm{~V}\left(\mathrm{~mA} \mathrm{~cm}^{-2}\right)$ & 47 & 67 & 50 & 49 \\
\hline & I at $-0.3 \mathrm{~V}\left(\mathrm{~mA} \mathrm{~cm}^{-2}\right)$ & 80 & 93 & 78 & 77 \\
\hline & $\operatorname{Rs}\left(\Omega \mathrm{cm}^{-2}\right)$ & 7.5 & 5.8 & 7.2 & 4.9 \\
\hline
\end{tabular}


Table 6

Anodic off-gas data of $5 \% \mathrm{AC}, \mathrm{AC}-\mathrm{HNO}_{3}$ and $\mathrm{AC}-\mathrm{HCl}$ at $600-800{ }^{\circ} \mathrm{C}$ with $600 \mathrm{rpm}$

\begin{tabular}{|c|c|c|c|c|c|c|c|c|c|}
\hline \multicolumn{2}{|c|}{$\mathrm{AC}$} & $\begin{array}{l}X_{\text {Ar }} \\
(\%) \\
\end{array}$ & $\begin{array}{l}X_{\mathrm{CO}} \\
(\%) \\
\end{array}$ & $\begin{array}{c}X_{\mathrm{CO} 2} \\
(\%) \\
\end{array}$ & $\begin{array}{c}Q_{\text {Total }} \\
\left(\mathrm{ml} \mathrm{s}^{-1}\right)\end{array}$ & $\begin{array}{c}Q_{\mathrm{CO} 2} \\
\left(\mathrm{ml} \mathrm{s}^{-1}\right)\end{array}$ & $\mathbf{Y}_{\mathrm{CO} 2}$ & $\begin{array}{c}\mathbf{Q}_{(\mathrm{CO} 2+\mathrm{CO})} \\
\left(\mathrm{ml} \mathrm{s}^{-1}\right)\end{array}$ & $\mathbf{Y}_{(\mathrm{CO} 2+\mathrm{CO})}$ \\
\hline \multirow{2}{*}{$600^{\circ} \mathrm{C}$} & I-off & 97.2 & 0.3 & 2.1 & $1.34(2)$ & \multirow{2}{*}{$0.015(2)$} & \multirow{2}{*}{$0.59(5)$} & \multirow{2}{*}{$0.017(2)$} & \multirow{2}{*}{$0.65(6)$} \\
\hline & $\mathrm{I}=0.10 \mathrm{~A}$ & 96.4 & 0.4 & 3.1 & $1.42(2)$ & & & & \\
\hline \multirow{2}{*}{$700{ }^{\circ} \mathrm{C}$} & I-off & 90.6 & 5.3 & 3.8 & $1.38(2)$ & \multirow{2}{*}{$0.032(3)$} & \multirow{2}{*}{$0.63(6)$} & \multirow{2}{*}{$0.036(3)$} & \multirow{2}{*}{$0.70(7)$} \\
\hline & $\mathrm{I}=0.20 \mathrm{~A}$ & 88.9 & 5.2 & 5.7 & $1.47(2)$ & & & & \\
\hline \multirow{2}{*}{$800^{\circ} \mathrm{C}$} & I-off & 89.9 & 9.0 & 0.9 & $1.41(2)$ & \multirow{2}{*}{$0.014(2)$} & \multirow{2}{*}{$0.28(2)$} & \multirow{2}{*}{$0.053(5)$} & \multirow{2}{*}{$1.03(10)$} \\
\hline & $\mathrm{I}=0.20 \mathrm{~A}$ & 87.0 & 11.1 & 1.8 & $1.50(3)$ & & & & \\
\hline \multicolumn{10}{|c|}{$\mathrm{AC}-\mathrm{HNO}_{3}$} \\
\hline \multirow{2}{*}{$600^{\circ} \mathrm{C}$} & I-off & 96.9 & 0.4 & 2.5 & $1.36(2)$ & \multirow{2}{*}{$0.018(2)$} & \multirow{2}{*}{$0.71(6)$} & \multirow{2}{*}{$0.019(2)$} & \multirow{2}{*}{$0.73(7)$} \\
\hline & $\mathrm{I}=0.10 \mathrm{~A}$ & 95.7 & 0.4 & 3.6 & $1.45(2)$ & & & & \\
\hline \multirow{2}{*}{$700^{\circ} \mathrm{C}$} & I-off & 91.0 & 4.7 & 3.9 & $1.38(2)$ & \multirow{2}{*}{$0.038(4)$} & \multirow{2}{*}{$0.75(7)$} & \multirow{2}{*}{$0.041(4)$} & \multirow{2}{*}{$0.79(8)$} \\
\hline & $\mathrm{I}=0.20 \mathrm{~A}$ & 89.1 & 4.5 & 6.2 & $1.49(2)$ & & & & \\
\hline \multirow{2}{*}{$800^{\circ} \mathrm{C}$} & I-off & 88.9 & 9.8 & 1.1 & $1.44(2)$ & \multirow{2}{*}{$0.024(2)$} & \multirow{2}{*}{$0.46(5)$} & \multirow{2}{*}{$0.049(5)$} & \multirow{2}{*}{$0.96(10)$} \\
\hline & $\mathrm{I}=0.20 \mathrm{~A}$ & 86.6 & 10.6 & 2.5 & $1.56(2)$ & & & & \\
\hline \multicolumn{10}{|c|}{ AC-HCl } \\
\hline \multirow{2}{*}{$600^{\circ} \mathrm{C}$} & I-off & 97.0 & 0.4 & 2.2 & $1.36(2)$ & & & & \\
\hline & $\mathrm{I}=0.10 \mathrm{~A}$ & 95.9 & 0.3 & 3.3 & $1.43(2)$ & $0.010(2)$ & $0.03(0)$ & $0.018(2)$ & $0.05(1)$ \\
\hline $700^{\circ} \mathrm{C}$ & I-off & 91.0 & 4.8 & 3.9 & $1.37(2)$ & $0034(3)$ & $066(6)$ & & $080(8)$ \\
\hline $100 \mathrm{C}$ & $\mathrm{I}=0.20 \mathrm{~A}$ & 88.9 & 5.0 & 5.9 & $1.47(2)$ & $0.034(3)$ & $0.00(0)$ & $0.042(4)$ & $0.00(0)$ \\
\hline & I-off & 89.4 & 9.2 & 1.3 & $1.39(2)$ & & & & \\
\hline & $\mathrm{I}=0.20 \mathrm{~A}$ & 86.9 & 10.8 & 2.2 & $1.49(2)$ & $0.015(2)$ & $0.50(3)$ & $0.050(5)$ & $0.95(10)$ \\
\hline
\end{tabular}

$\mathrm{X}_{\mathrm{Ar}}, \mathrm{X}_{\mathrm{CO}}$ and $\mathrm{X}_{\mathrm{CO} 2}$ - concentration of Ar, $\mathrm{CO}$ and $\mathrm{CO}_{2}$ in anodic off-gas by $\mathrm{GC}$ analysis

$\mathrm{Q}_{\text {Total }}$ - total anodic off-gas evolution rate by bubble-meter measurement

$\mathrm{Q}_{\mathrm{CO} 2}$ - net electrochemical $\mathrm{CO}_{2}$ evolution rate are calculated by Eq. (8)

$\mathrm{Y}_{\mathrm{CO} 2}$ - electrochemical $\mathrm{CO}_{2}$ yield are calculated by Eq. (9)

$\mathrm{Q}_{(\mathrm{CO} 2+\mathrm{CO})}$ - net electrochemical $\mathrm{CO}_{2}$ and $\mathrm{CO}$ evolution rate are calculated by Eq. (10)

$\mathrm{Y}_{(\mathrm{CO} 2+\mathrm{CO})}$ - electrochemical $\mathrm{CO}_{2}$ and $\mathrm{CO}$ yield are calculated by Eq. (11) 
Figure 1

Click here to download Figure(s): Figure1-rev.doc

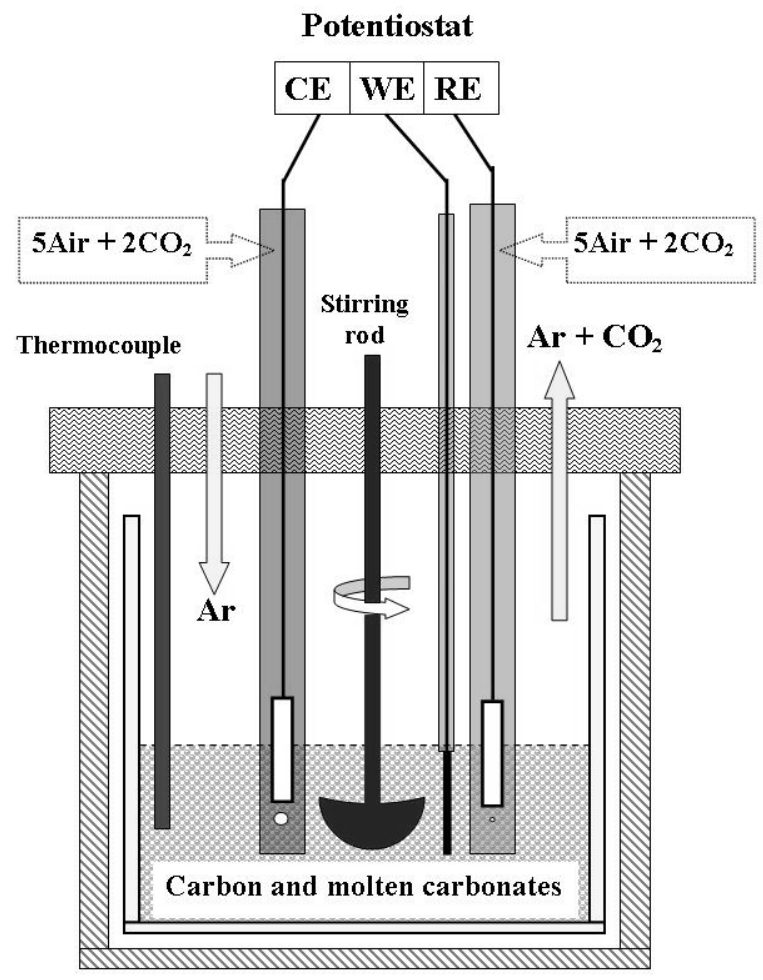


Figure 2

Click here to download Figure(s): Figure2-rev.doc

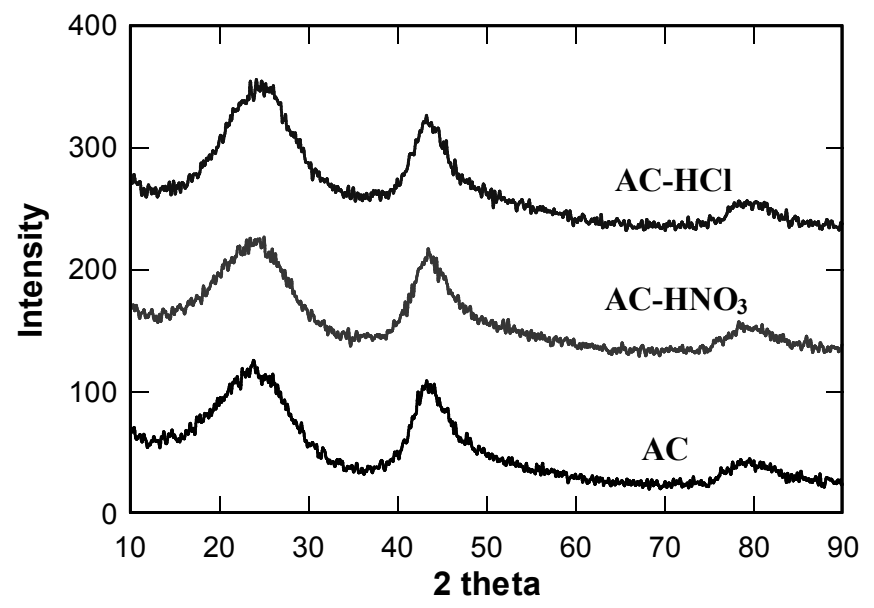


Figure 3

Click here to download Figure(s): Figure3-rev.doc

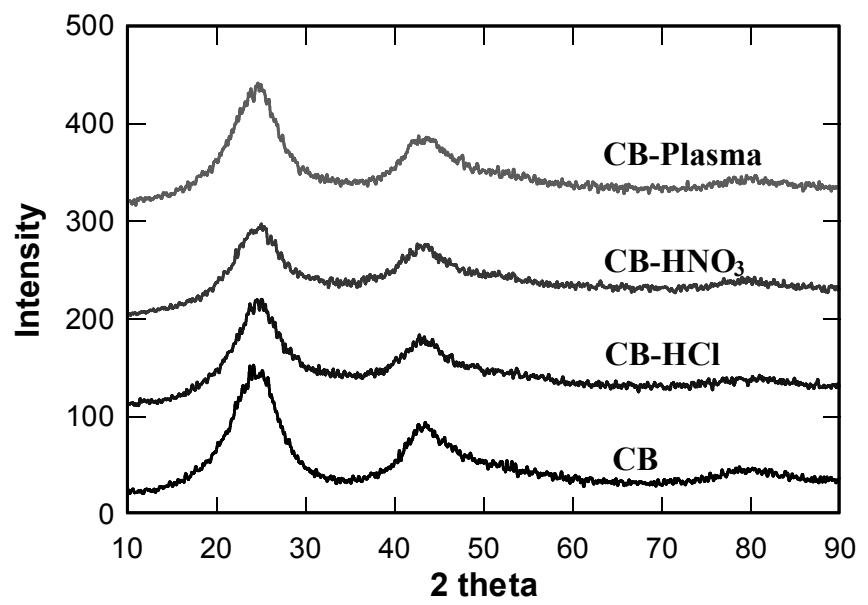


Figure 4

Click here to download Figure(s): Figure4-rev.doc

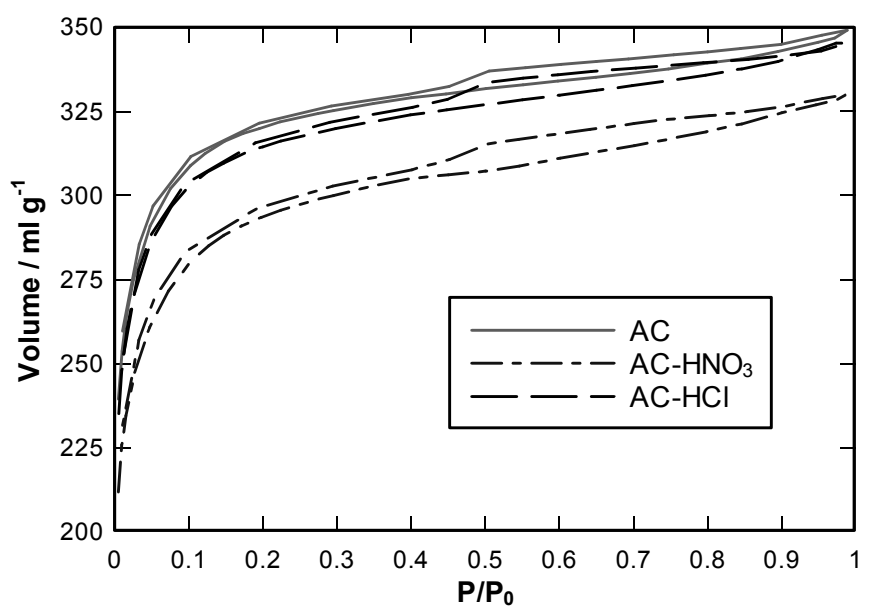


Figure 5

Click here to download Figure(s): Figure5-rev.doc

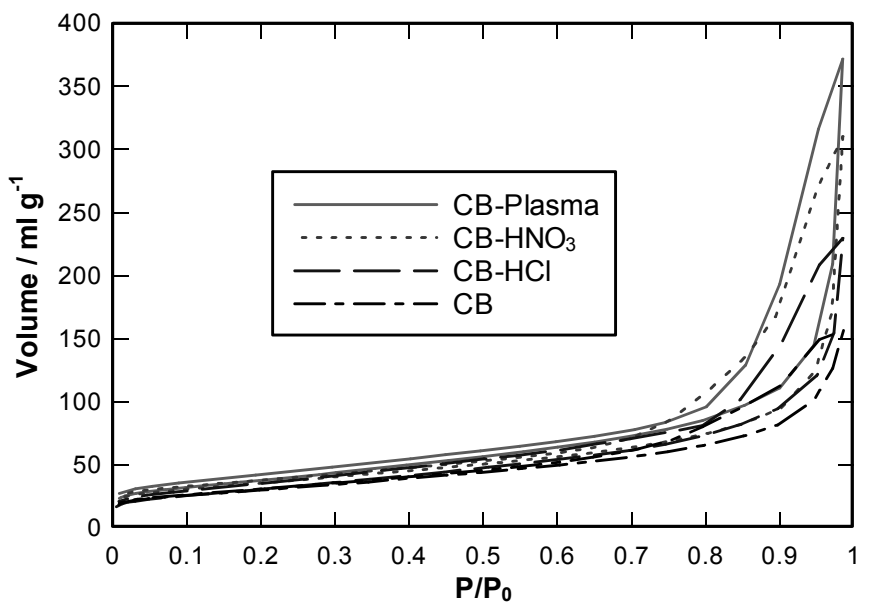


Click here to download Figure(s): Figure6-rev.doc

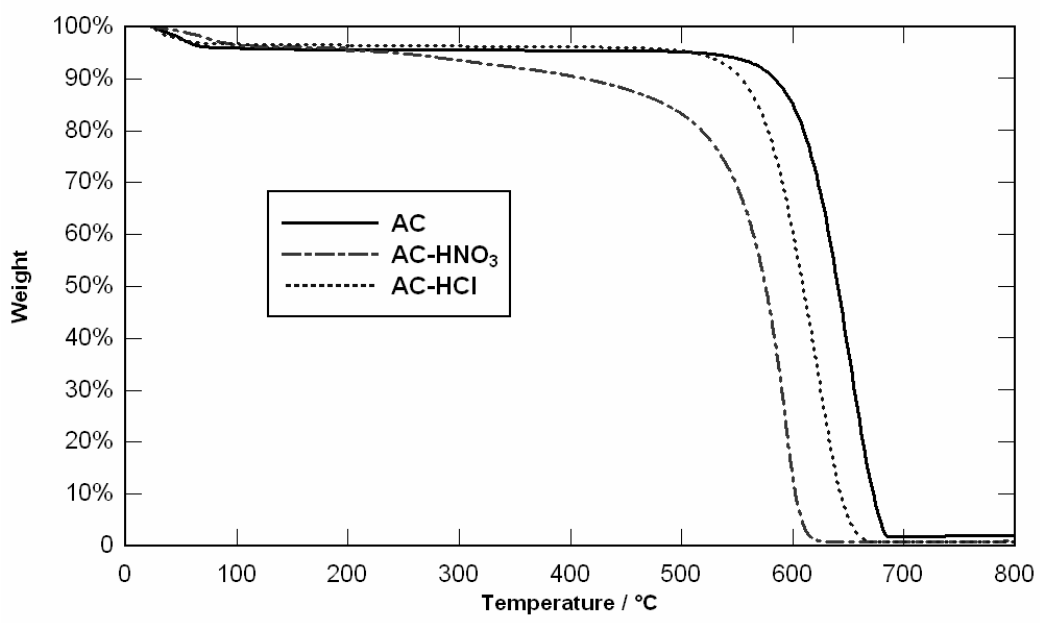




\section{Click here to download Figure(s): Figure7-rev.doc \\ Click here to download Figure(s): Figure7-rev.doc}

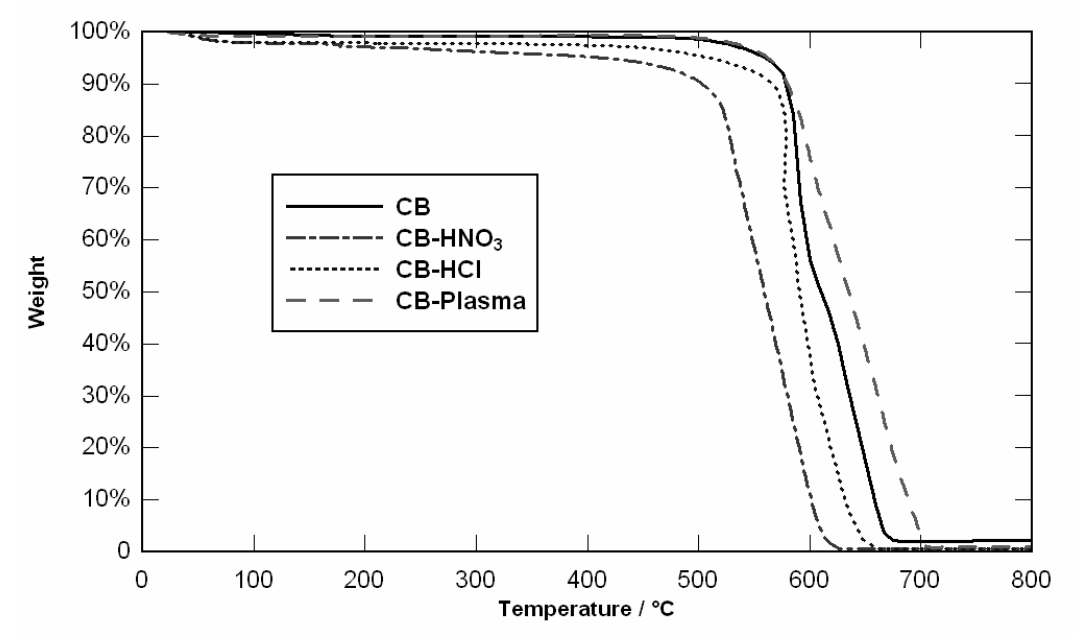

Figure 7 
Figure 8

Click here to download Figure(s): Figure8-rev.doc
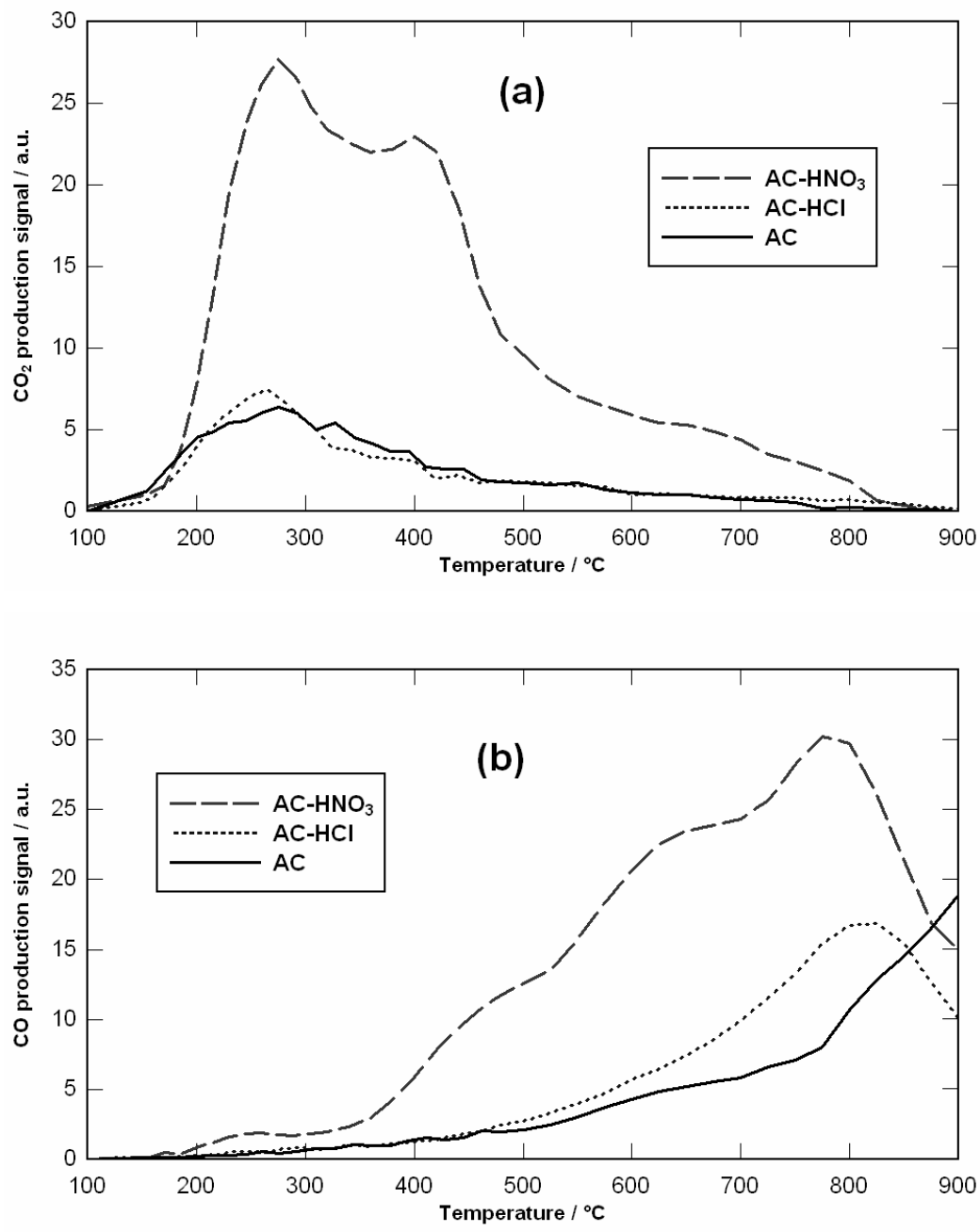
Figure 9

Click here to download Figure(s): Figure9-rev.doc
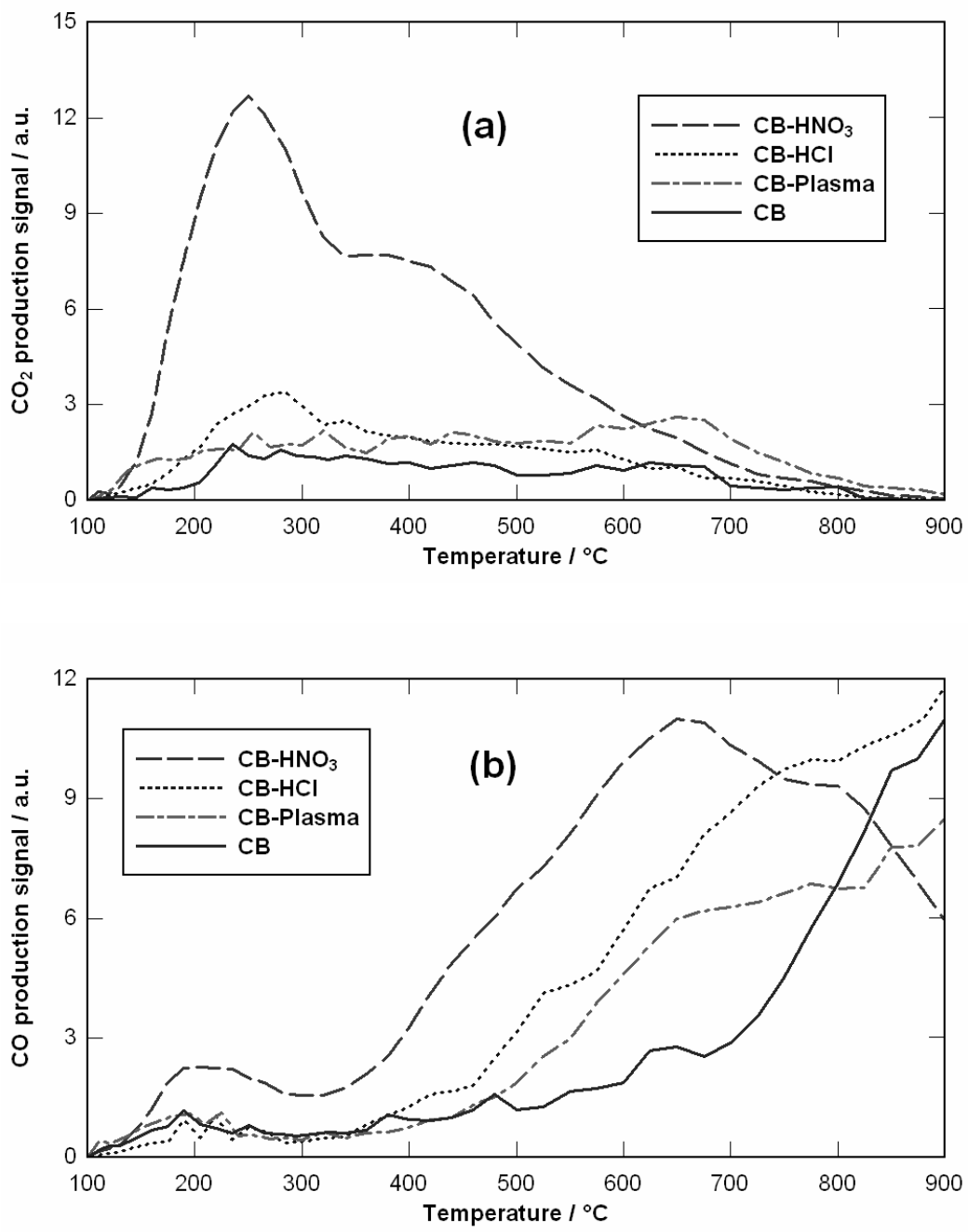


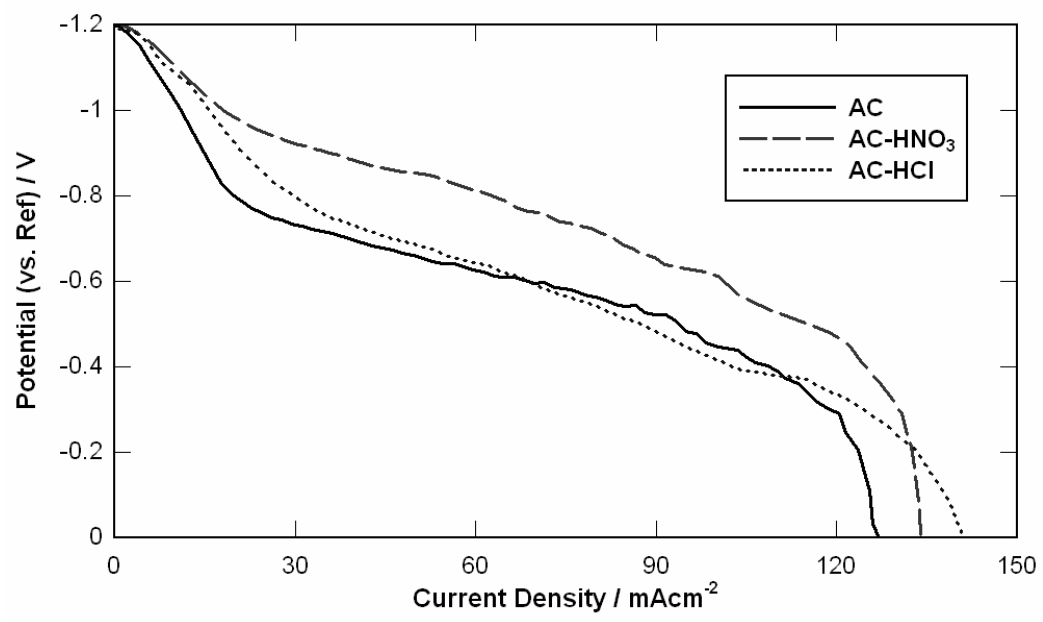

Fig.10 Polarization curves of $5 \%$ AC series carbon fuels at $700{ }^{\circ} \mathrm{C}$ with $600 \mathrm{rpm}$ stirring 
Figure 11

Click here to download Figure(s): Figure11-rev.doc

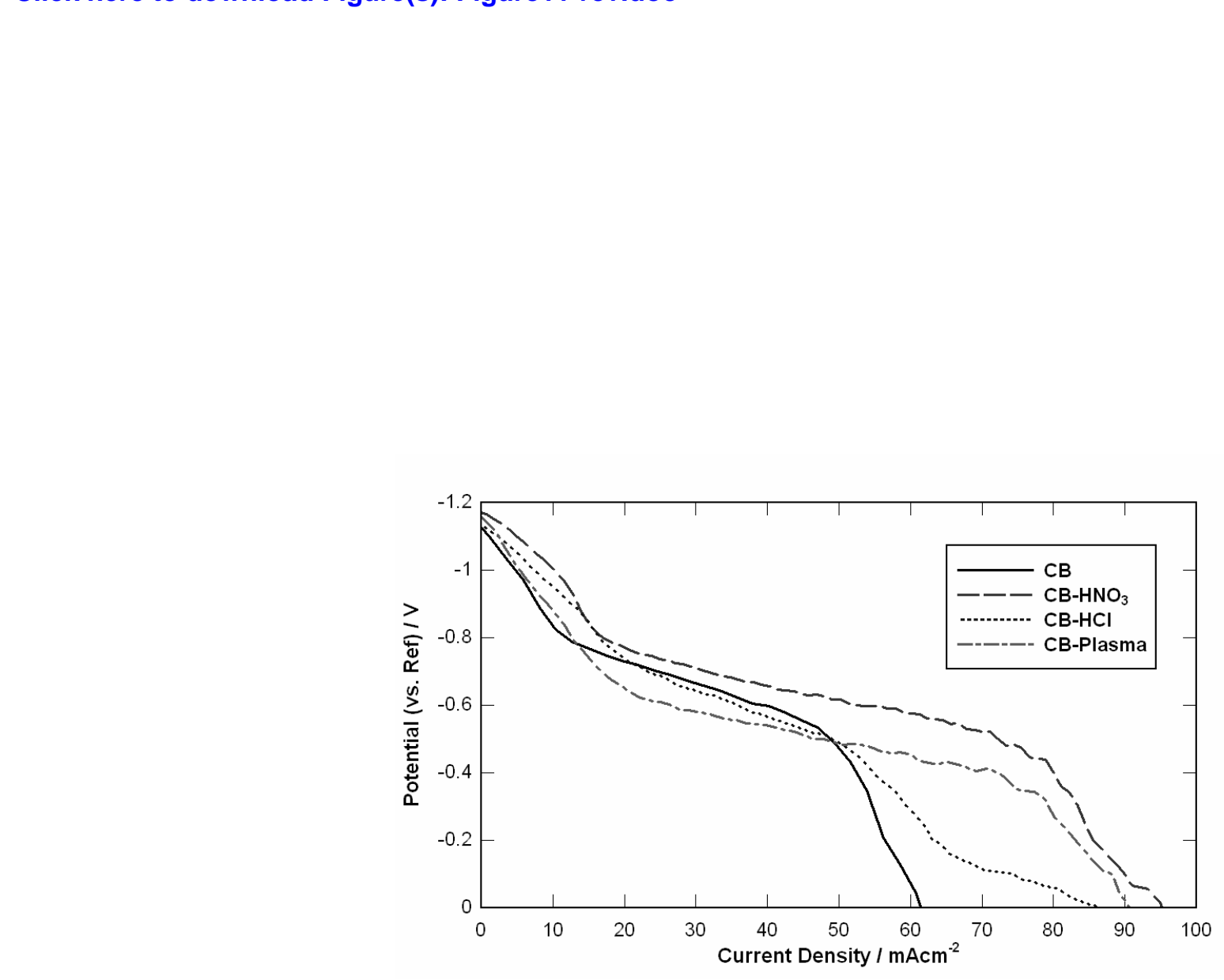

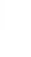


Click here to download Figure(s): Figure12-rev.doc

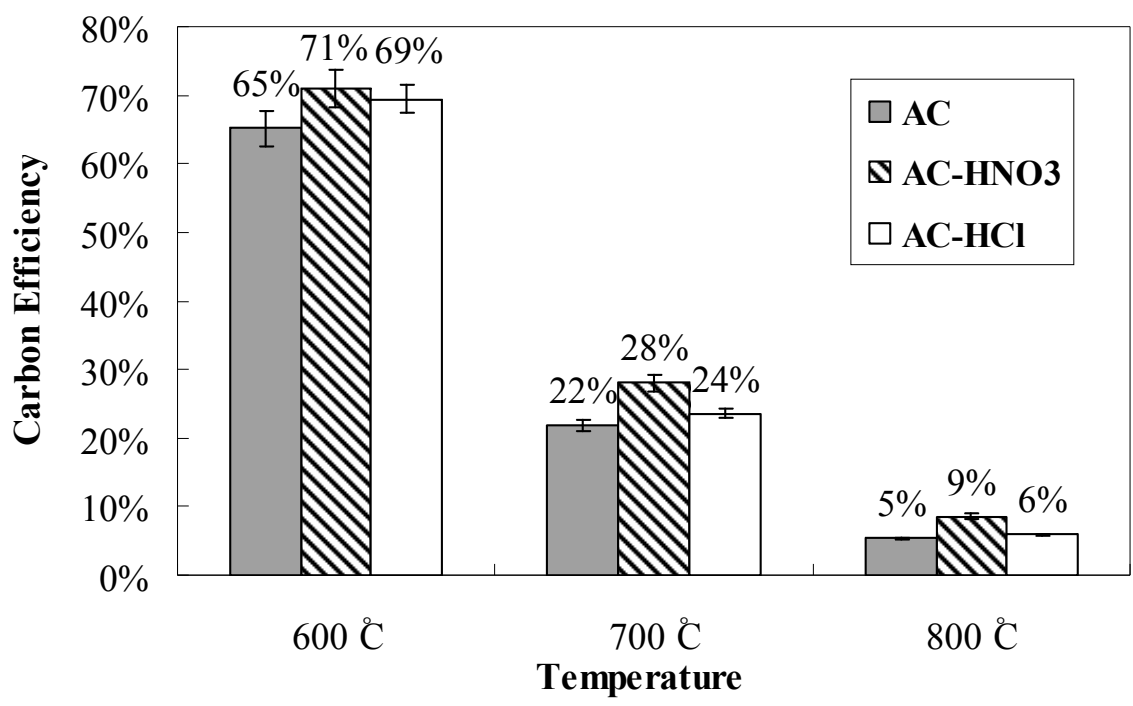

